\title{
Analisis Kinerja Ekspor Alas Kaki Indonesia Ke Kawasan Asean
}

\author{
Widya Nadira Nasution ${ }^{1}$, Sri Mulatsih ${ }^{2}$ \\ Departemen Ilmu Ekonomi, Fakultas Ekonomi dan Manajemen, Institut Pertanian Bogor \\ Jl. Agatis, Kampus IPB Darmaga, Bogor 16680, Indonesia \\ *Korespondensi: mulatsupardi@yahoo.co.id
}

[diterima: Juli 2019- revisi: Agustus 2019-diterbitkan daring: Desember 2019]

\begin{abstract}
ABSTRAK
Ekspor utama alas kaki Indonesia adalah ke Amerika Serikat dan beberapa negara di Eropa, sedangkan untuk kawasan terdekat dengan Indonesia, seperti ASEAN, nilai ekspor alas kaki Indonesia cukup rendah. Penelitian ini bertujuan untuk menganalisis daya saing dan kinerja ekspor alas kaki Indonesia ke kawasan ASEAN tahun 2010-2014. Negara mitra dalam penelitian ini adalah Malaysia, Singapura, Thailand, Filipina, Vietnam, dan Brunei Darussalam. Analisis daya saing dilakukan dengan menggunakan indikator Revealed Comparative Advantages (RCA), Porter's Diamond, dan Export Product Dynamic (EPD). Hasil analisis RCA menunjukkan bahwa alas kaki Indonesia memiliki daya saing di semua negara kecuali Malaysia. Hasil model Porter's Diamond menunjukkan bahwa Indonesia memiliki daya saing yang kuat di sektor alas kaki. Hasil analisis EPD menunjukkan bahwa ekspor alas kaki ke sebagian besar negara mitra masuk dalam kriteria falling star. Selanjutnya, analisis kinerja ekspor alas kaki ke kawasan ASEAN dilakukan dengan menggunakan Gravity Model. Hasil analisis menunjukkan bahwa semua variabel berpengaruh signifikan terhadap kinerja ekspor alas kaki. PDB per kapita Indonesia, jarak ekonomi, dan harga ekspor berpengaruh negatif terhadap kinerja ekspor, sedangkan PDB per kapita negara mitra berpengaruh positif. Depresiasi nilai tukar berdampak positif terhadap peningkatan kinerja ekspor.
\end{abstract}

Kata kunci: EPD, ekspor alas kaki, gravity model, porter's diamond, RCA

\begin{abstract}
The main export of Indonesian footwear is to the United States and several countries in Europe, while for the nearest region to Indonesia, such as ASEAN, the export value of Indonesian footwear is quite low. This study aims to analyze the competitiveness and performance of Indonesian footwear exports to the ASEAN region in 2010-2014. The partner countries in this study are Malaysia, Singapore, Thailand, the Philippines, Vietnam, and Brunei Darussalam. Competitiveness analysis is carried out using Revealed Comparative Advantages (RCA), Porter's Diamond, and Export Product Dynamic (EPD) indicators. The results of the RCA analysis show that Indonesian footwear has competitiveness in all countries except for Malaysia. The results of the Porter's Diamond model show that Indonesia has strong competitiveness in the footwear sector. The results of the EPD analysis show that the footwear export to the majority of partner countries are in falling star criteria. Furthermore, the analysis of footwear exports performance to the ASEAN region is carried out using the Gravity Model. The results of the analysis show that all variables significantly affect the footwear export performance. Indonesia's GDP per capita, economic distance, and export prices have negative effect on export performance, while GDP per capita of partner countries has positive effect. Exchange rate depreciation has positive impact on improving export performance.
\end{abstract}

Keywords: EPD, footwear export, gravity model, porter's diamond, RCA 


\section{PENDAHULUAN}

Perdagangan internasional merupakan aspek penting dalam perekonomian suatu negara. Perdagangan internasional akan menciptakan suatu hubungan ekonomi antar satu negara dengan negara lain. Perdagangan internasional terdapat dua komponen penting yaitu ekspor dan impor. Ekspor merupakan salah satu penggerak pertumbuhan ekonomi. Ekspor Indonesia terbagi dua yaitu sektor migas dan non migas. Tabel 1 menunjukkan bahwa nilai ekspor non migas lebih tinggi dibandingkan migas. Hal ini mengindikasikan bahwa sektor non migas merupakan sektor penting dalam perekonomian Indonesia.

Tabel 1. Ekspor migas dan non migas Indonesia 2010-2014 (Juta US\$)

\begin{tabular}{lrrrrr}
\hline Komponen Ekspor & 2010 & 2011 & 2012 & 2013 & 2014 \\
\hline Migas & 28040 & 41477 & 36977 & 32633 & 30018 \\
Non Migas & 129740 & 162020 & 15304 & 149919 & 145961 \\
\hline Sumber: BPS 2017 & & & & &
\end{tabular}

Salah satu penyumbang terbesar dalam sektor non migas Indonesia adalah sub sektor industri. Perkembangan sub sektor industri terhadap ekspor pada tahun 2012-2015 sebesar 66.18 persen (Kemenperin 2015). Gambar 1 merupakan 10 komoditas unggulan ekspor
Indonesia di pasar internasional. Hasil industri dengan nilai ekspor terbesar berturut-turut adalah pengolahan kelapa sawit, besi baja dan otomotif, tekstil, elektronika, pengolahan karet, makanan dan minuman, pulp, pengolahan kayu, emas dan yang terakhir adalah kulit sepatu.

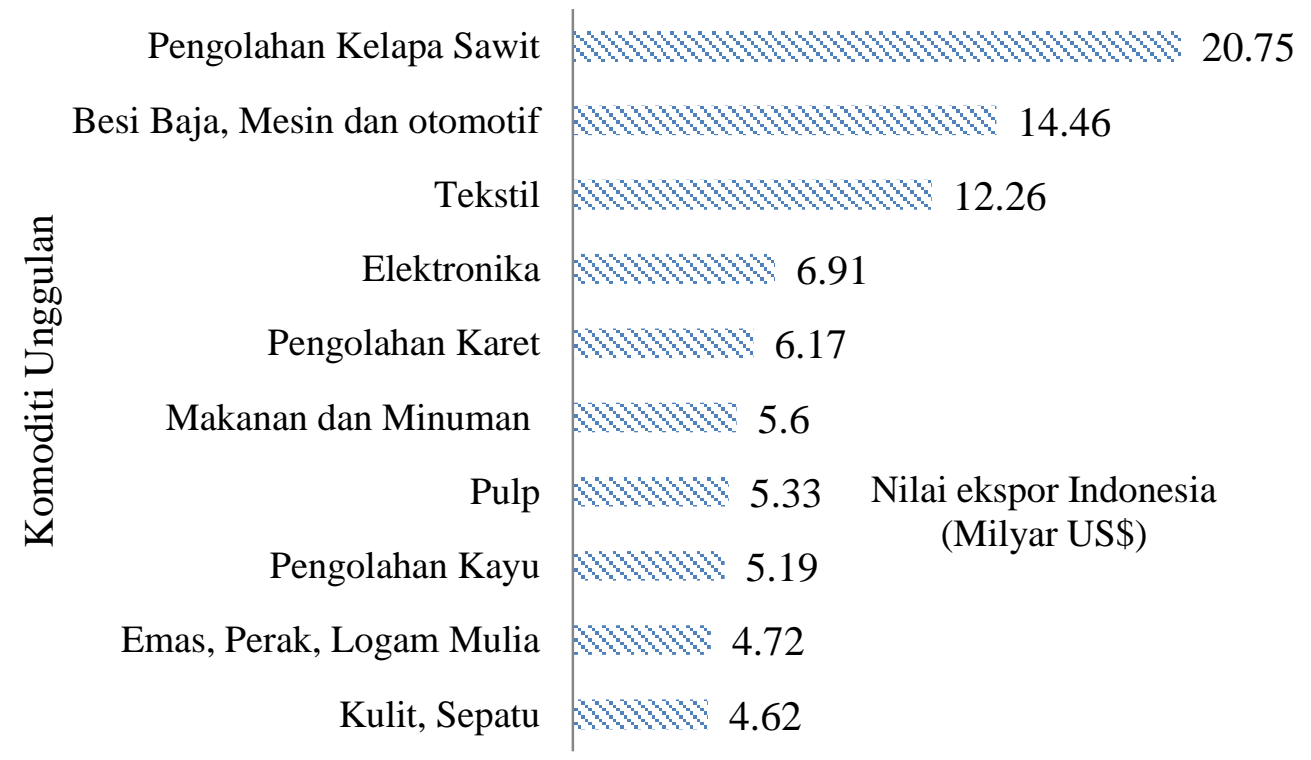

Sumber: Kementerian Perindustrian 2017

Gambar 1. Sepuluh Komoditas Unggulan Ekspor Indonesia Tahun 2015 (Milyar US\$)

Investasi industri alas kaki cenderung meningkat setiap tahunnya. Pada tiga tahun terakhir (2011-2014), kenaikan rata-rata mencapai 4.74 persen. Pada tahun 2014, nilai investasi disektor industri alas kaki sebesar $\mathrm{Rp}$ 10.7 triliun atau naik sekitar 1.25 persen dibanding tahun sebelumnya, dan mampu menyerap tenaga kerja sebanyak 643 ribu orang (Kemenperin 2014). Oleh karena itu, pemerintah terus mendorong ekspor alas kaki dengan menggelar pameran contohnya "Indonesia Leather and Footwear" setiap tahun untuk 
menarik pembeli. Hal itu merupakan upaya untuk menciptakan iklim usaha yang kondusif dan mendorong perkembangan industri.

Perkembangan industri alas kaki Indonesia dapat dilihat dari nilai ekspor alas kaki yang cenderung meningkat setiap tahunnya. Hal ini dapat dibuktikan pada Gambar 2, ekspor alas kaki Indonesia berfluktuatif tetapi cenderung meningkat. Pada tahun 2013 nilai ekspor alas kaki Indonesia mencapai USD 2.3 miliar. Dengan nilai tersebut Indonesia mampu memenuhi kebutuhan alas kaki dunia sekitar 3 persen dan omset yang dihasilkan dari komoditas ini juga hampir mencapai USD 2 miliar (Kemenperin 2013). Omset ini diharapkan dapat meningkat seiring dengan jumlah penduduk yang besar dan kondisi ekonomi yang membaik sehingga dapat memacu pertumbuhan penjualan sepatu di dalam negeri.

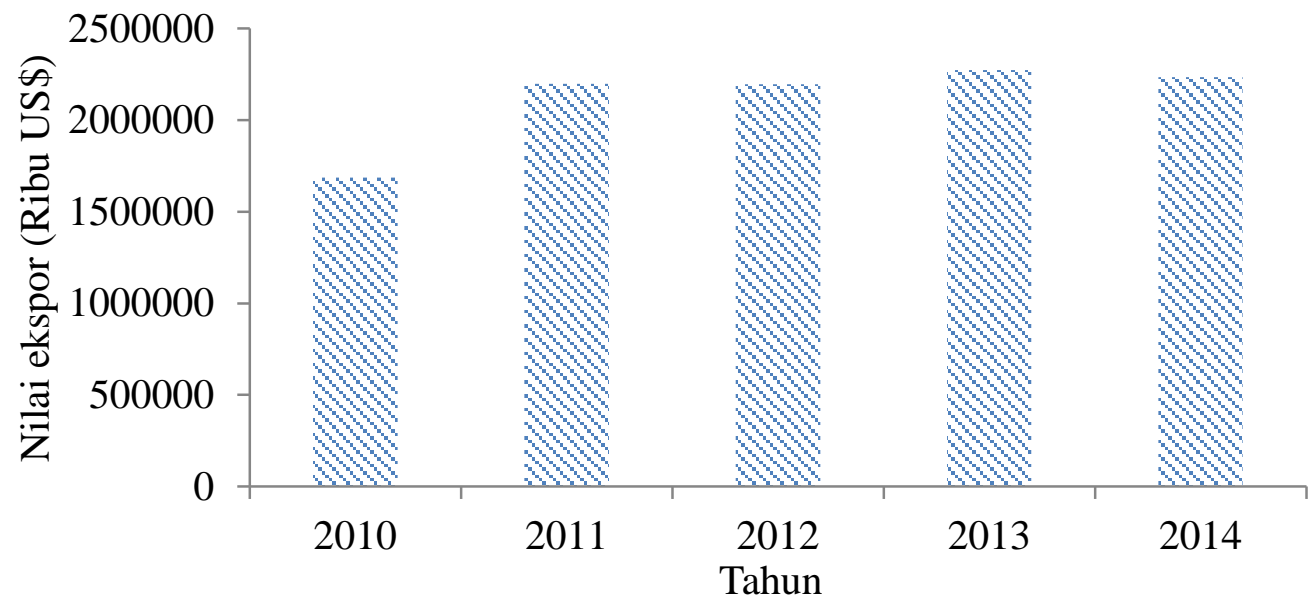

Sumber: UNCOMTRADE 2017

Gambar 2. Nilai Ekspor Alas Kaki Indonesia Periode 2010-2014 (Ribu US\$)

Negara tujuan utama ekspor alas kaki Indonesia diantaranya adalah Amerika Serikat, Eropa dan beberapa negara Asia. Tabel 2 menggambarkan nilai ekspor alas kaki menurut negara tujuan utama. Negara tujuan ekspor alas kaki Indonesia didominasi oleh Negara di bagian Eropa. Ekspor alas kaki tinggi di Eropa disebabkan oleh beberapa faktor, misalnya di Italia harga sepatu sangat tinggi karena mempertahankan kualitas sepatu sehingga masyarakat lebih menyukai alas kaki negara lain yang harganya lebih murah. Sementara untuk negara yang dekat Indonesia seperti kawasan Asia, nilai ekspor alas kaki Indonesia cenderung rendah. Padahal untuk kawasan tersebut, telah terbentuk beberapa kerjasama misalnya kerjasama ASEAN.
Kerjasama ASEAN tentu memberikan banyak manfaat kepada industri alas kaki Indonesia seperti mempermudah arus masuk investasi ke Indonesia, meningkatkan pemasaran produk alas kaki Indonesia ke negara ASEAN, dan transfer teknologi sehingga dapat meningkatkan dayasaing alas kaki Indonesia di kawasan ASEAN. Namun, kerjasama ASEAN juga menimbulkan dampak negatif dimana salah satunya produk dari Negara-negara ASEAN akan mudah masuk ke Indonesia sehingga produk Indonesia harus mampu berdayasaing agar dapat bertahan di pasar domestik dan pasar internasional. Salah satu penyebab ekspor alas kaki Indonesia cenderung rendah ke negara kawasan ASEAN adalah banyaknya pesaing alas kaki Indonesia ke kawasan ASEAN misalnya alas kaki dari Vietnam dan Myanmar.

Tabel 2. Negara Tujuan Utama Ekspor Alas Kaki Indonesia Periode 2010-2014 (Ribu US\$)

\begin{tabular}{llcccc}
\hline Negara Tujuan & $\mathbf{2 0 1 0}$ & $\mathbf{2 0 1 1}$ & $\mathbf{2 0 1 2}$ & $\mathbf{2 0 1 3}$ & $\mathbf{2 0 1 4}$ \\
\hline Jepang & 99939.6 & 143349.0 & 176394.1 & 216136.0 & 229528.6
\end{tabular}




\begin{tabular}{lccccr}
\hline Negara Tujuan & $\mathbf{2 0 1 0}$ & $\mathbf{2 0 1 1}$ & $\mathbf{2 0 1 2}$ & $\mathbf{2 0 1 3}$ & \multicolumn{2}{c}{$\mathbf{2 0 1 4}$} \\
\hline Singapura & 45312.1 & 53782.4 & 60720.2 & 72830.8 & 64129.3 \\
Amerika Serikat & 564083.5 & 721690.5 & 890483.9 & 1032671.4 & 1120594.7 \\
Inggris & 196495.2 & 226679.8 & 227562.2 & 220502.4 & 246839.0 \\
Belanda & 150718.2 & 209630.1 & 194678.9 & 193895.3 & 174028.0 \\
Jerman & 212818.7 & 273460.8 & 254415.4 & 261241.5 & 263442.0 \\
Belgia & 213578.1 & 295186.5 & 303081.3 & 296819.3 & 342832.5 \\
Italia & 164602.2 & 187771.1 & 146548.3 & 137769.9 & 135253.4 \\
Spanyol & 37398.7 & 52899.6 & 50470.7 & 45067.0 & 47381.1 \\
Slovakia & 24125.8 & 18630.4 & 18534.1 & 17330.8 & 8269.5 \\
\hline
\end{tabular}

Sumber: BPS 2017

Adanya pesaing alas kaki dari negara lain, maka Indonesia perlu meningkatkan dayasaing agar dapat menghadapi tantangan di pasar internasional, khususnya di negara kawasan ASEAN. Berdasarkan uraian rumusan masalah diatas, maka tujuan dalam penelitian ini adalah:

1. Menganalisis dayasaing komparatif produk alas kaki Indonesia di kawasan ASEAN selama periode 2010 sampai 2014.

2. Menganalisis dinamika dayasaing ekspor alas kaki Indonesia ke kawasan ASEAN periode 2010 sampai 2014.

3. Menganalisis faktor-faktor yang memengaruhi ekspor alas kaki Indonesia di kawasan ASEAN selama periode 2010 sampai 2014.

4. Menganalisis dayasaing kompetitif produk alas kaki Indonesia di kawasan ASEAN selama periode 2010 sampai 2014.

\section{TINJAUAN PUSTAKA}

\section{Teori Perdagangan Internasional}

Globalisasi yang terjadi saat ini menjadikan perdagangan tidak hanya dilakukan dalam satu negara saja, melainkan dengan negara lain. Perdagangan internasional tercermin dari kegiatan ekspor impor suatu negara yang menjadi salah satu komponen dalam pembentukan GDP (Gross Domestic Bruto). Teori perdaganga semakin terus berkembang mulai dari teori keunggulan absolut oleh Adam Smith dan teori keunggulan komparatif oleh David Ricardo.
Peningkatan ekspor akan menjadi salah satu faktor untuk meningkatkan GDP suatu negara (Oktaviani dan Novianti, 2009).

Gambar 3 menggambarkan perdagangan antara negara $\mathrm{X}$ dan negara $\mathrm{Y}$. DX dan SX masing-masing merupakan kurva permintaan dan penawaran untuk negara X sedangkan DY dan SY adalah kurva permintaan dan penawaran untuk negara $Y$. Untuk negara X, kondisi harga yang lebih tinggi dari $\mathrm{P} 1$ menyebabkan negara $\mathrm{X}$ akan mengalami kelebihan penawaran dari komoditi M sehingga kurva penawaran ekspornya diperlihatkan oleh panel B. Di lain pihak, untuk negara $\mathrm{Y}$ apabila harga yang berlaku lebih kecil dari P3 maka negara Y akan mengalami peningkatan permintaan (konsumen akan meminta lebih banyak karena harga yang relatif murah). Sehingga tingkat permintaan lebih tinggi daripada produksi domestiknya. Hal ini akan mendorong negara $\mathrm{Y}$ mengimpor kekurangan atas komoditi tersebut dari negara yang mengalami kelebihan produksi, yaitu negara $\mathrm{X}$.

Berdasarkan harga relatif P1, kuantitas komoditi $\mathrm{M}$ yang ditawarkan akan sama dengan kuantitas yang diminta untuk negara $X$. untuk negara $\mathrm{Y}$, brdasarkan harga relatif $\mathrm{P} 3$, kuantitas produk $M$ yang ditawarkan sama dengan yang diminta. Pada saat berlangsungnya perdagangan internasional antara negara $\mathrm{X}$ dan $\mathrm{Y}$ tingkat harga berada pada titik P2 dan mengambil asumsi bahwa tidak ada biaya transportasi dalam proses 
perdagangan sehingga negara $\mathrm{X}$ akan mengekspor hasil kelebihan produksinya. Sementara karena tingkat harga domestik negara Y berada pada P3, maka negara $\mathrm{Y}$ akan mengimpor kekurangan produksinya. Hubungan penawaran dan permintaan kedua negara tersebut pada tingkat harga P2 akan menyebabkan terjadinya keseimbangan internasional di titik $\mathrm{E}^{*}$ (panel B). Kurva S dan D pada panel B menunjukkan tingkat penawaran dan permintaan yang terjadi dalam perdagangan internasional (Salvatore,1997).

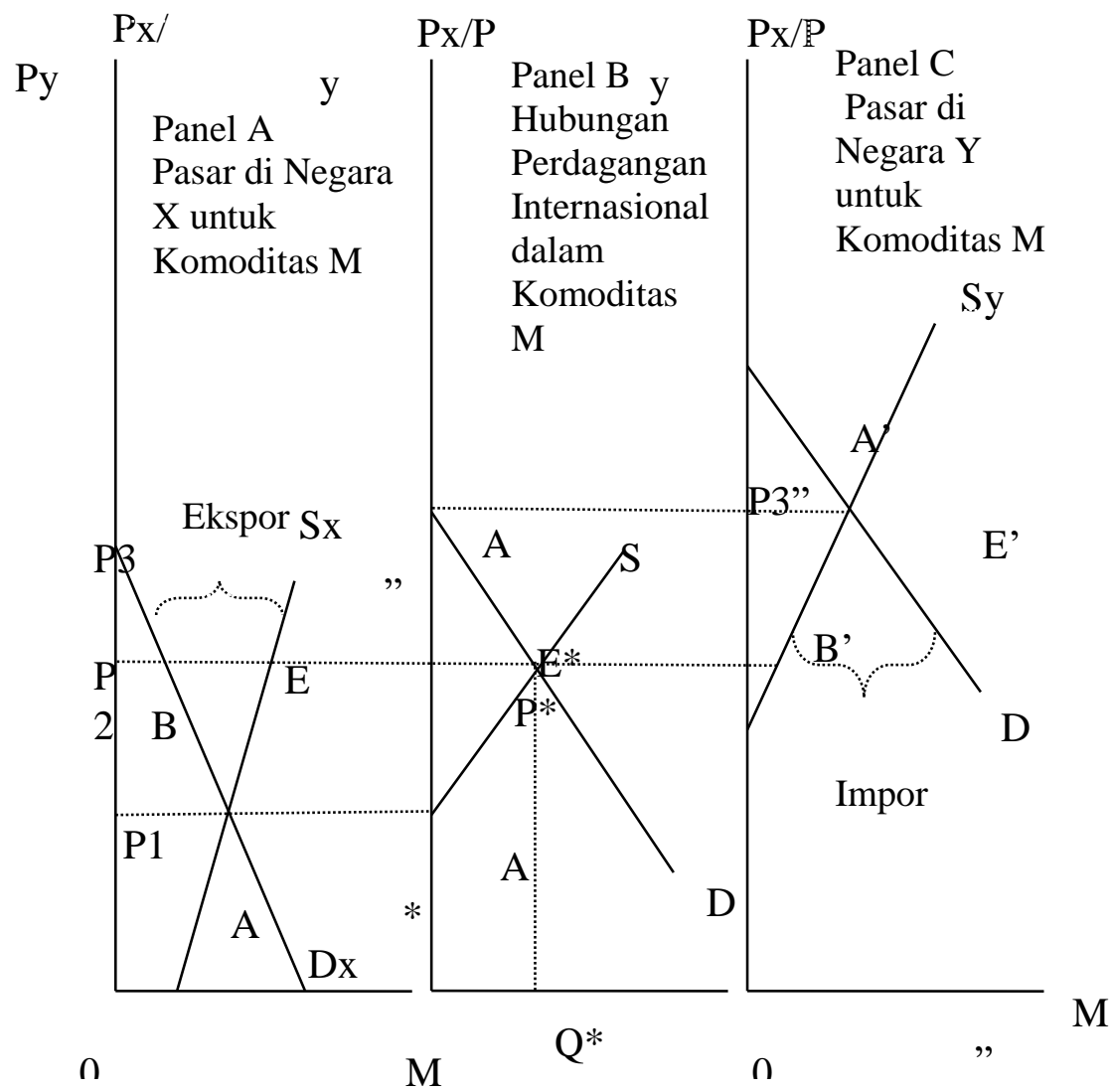

Sumber:Salvatore, 1997

Gambar 3. Kurva Perdagangan Internasional

\section{Teori Dayasaing}

Dayasaing dapat diidentikkan dengan produktivitas, yaitu tingkat output yang dihasilkan untuk setiap input yang digunakan (Porter,1990). Peningkatan produktivitas ini dapat disebabkan oleh jumlah input fisik modal dan tenaga kerja, peningkatan kualitas input yang digunakan dan peningkatan teknologi. Suatu negara dapat berdayasaing apabila negara tersebut mampu untuk menekan biaya produksinya serendah mungkin dengan kualitas yang baik. Keunggulan dalam dayasaing dapat dijelaskan oleh dua teori yaitu teori keunggulan komparatif dan keunggulan kompetitif.

\section{Teori Keunggulan Komparatif}

Sebuah negara yang kurang efisien dibanding negara lain dalam memproduksi kedua komoditi, namun tetap terdapat dasar untuk melakukan perdagangan yang menguntungkan kedua belah pihak. Negara pertama harus melakukan spesialisasi dalam memproduksi dan mengekspor komoditi yang memiliki kerugian absolut lebih kecil dan mengimpor komoditi yang memiliki kerugian absolut lebih besar. Dalam konteks dua negara dan dua komoditi, jika salah satu negara telah ditetapkan memiliki keunggulan komparatif dalam satu komoditi, maka negara satunya harus dianggap memiliki keunggulan komparatif dalam komoditi lainnya (Salvatore, 1997) . 
RCA (Revealed Comparative Advantage). RCA merupakan sebuah indeks untuk mengukur keuntungan maupun kerugian relatif komoditi tertentu pada suatu negara yang tercermin pada pola perdagangannya. Fungsi dari RCA adalah untuk mengetahui komoditas apa saja yang memiliki keunggulan komparatif dari suatu negara ke negara tujuan dalam suatu waktu tertentu sehingga dapat dianalisis bagaimana dayasaing negara tersebut. Variabel yang diukur pada metode ini diantaranya kinerja ekspor suatu produk pada wilayah terhadap total ekspor wilayah tersebut yang kemudian dibandingkan dengan pangsa nilai produk dalam perdagangan dunia.

\section{Teori Keunggulan Kompetitif}

Suatu perusahaan akan mendominasi pasar melalui strategi yang diciptakan oleh perusahaan tersebut. Kemampuan perusahaan mencapai skala ekonomi terlebih dahulu dibanding perusahaan lain akan memberi keuntungan lebih banyak lagi. Strategi akan menciptakan keunggulan kompetitif melalui kesempatan dalam pasar secara keseluruhan.

Model Porter's Diamond. Porter's diamond menunjukkan kondisi dayasaing kompetitif suatu komoditi. Keunggulan kompetitif suatu komoditi merupakan keunggulan yang tidak bergantung pada kondisi alami suatu komoditas. Dayasaing dapat diidentifikasikan dengan tingkat output yang dihasilkan untuk setiap input yang digunakan. Kondisi faktor, kondisi permintaan, industri penunjang, struktur, strategi dan persaingan komoditi, kebijakan pemerintah dan kesempatan merupakan faktor penting dalam meningkatkan dayasaing komoditi suatu negara.

\section{Jarak Ekonomi}

Jarak ekonomi merupakan ukuran dari biaya transportasi yang dihadapi oleh suatu negara dalam melakukan ekspor. Jarak ekonomi mencerminkan biaya transportasi. Semakin jauh jarak antar kedua negara maka akan meningkatkan biaya transportasi dan mengurangi nilai ekspor. Jarak ekonomi diukur dengan jarak geografis suatu negara dengan negara tujuan dikalikan dengan perbandingan antara GDP total negara tujuan ekspor dengan jumlah GDP total seluruh negara tujuan ekspor yang diteliti. Jarak ekonomi dirumuskan sebagai berikut:

Jarak ekonomi $=$ jarak geografis $\mathrm{x} \frac{G D P}{\sum_{i=1}^{6} G D P}$

Dimana:

GDP $=$ GDP ASEAN pada tahun ke-t

$\sum_{i=1}^{6} G D P=$ GDP total negara ASEAN yang dianalisis pada tahun ke-t

\section{Harga}

Harga merupakan salah satu faktor yang memengaruhi ekspor. Jika harga suatu komoditi meningkat maka akan menurunkan ekspor komoditi tersebut (cateris paribus). Ketika terjadi penurunan harga ekspor, suatu negara akan berusaha untuk mempertahankan pendapatan ekspornya, sehingga akan meningkatkan volume ekspor. Harga Ekspor dirumuskan sebagai berikut:

$\mathrm{PE}=\frac{\text { Nilai ekspor komoditi alas kaki }}{\text { Volume ekspor komoditi alas kaki }}$

\section{Real Effective Exchange Rate(REER)}

Nilai tukar adalah tingkat harga yang disepakati oleh dua negara dalam melakukan kegiatan perdagangan. Nilai tukar dibedakan menjadi dua jenis yaitu nilai tukar nominal dan nilai tukar riil. Real effective exchange rate (REER) dihitung dengan indeks nominal effective exchange rate yang disesuaikan dengan harga relatif dan biaya ekonomi suatu negara dengan negara lain. Sehingga perubahan pada REER akan memengaruhi perkembangan nilai tukar nominal.

\section{Penelitian Terdahulu}

Penelitian Hakim dan Dahalan (2009) berjudul krisis keuangan global dan integrasi ekonomi: bukti pada negara ASEAN-5. Variabel yang digunakan antara lain ekspor, GDP, populasi dan jarak antar negara. Metode yang digunakan adalah gravity model. Hasil penelitian menunjukkan bahwa indeks krisis keuangan memberi efek negatif pada integrasi ekonomi negara ASEAN-5. Hasil akhirnya mengindikasikan bahwa integrasi ekonomi 
mungkin untuk diimplementasikan pada negara ASEAN-5. Tetapi, krisis keuangan global akan menjadi ancaman bagi integrasi ekonomi.

Penelitian oleh Kusuma dan Firdaus (2015) melihat dayasaing dan faktor yang memengaruhi volume ekspor sayuran Indonesia terhadap negara tujuan utama menggunakan gravity model, RCA (Revealed Comparative Advantages) dan EPD (Export Product Dynamic). Periode yang digunakan dalam penelitian ini adalah tahun 2008 sampai 2012. Hasil penelitian menunjukkan bahwa komoditas sayuran Indonesia tidak memiliki keunggulan komparatif lebih baik dibandingkan dengan negara pesaingnya, yaitu Belanda dan China pada komoditas kentang, tomat, bawang, kubis, dan cabe terhadap dunia. Keunggulan komparatif sayuran Indonesia terhadap negara tujuannya dihasilkan oleh tomat, kubis, dan cabai dengan negara tujuan yang berbeda dari masing-masing komoditas. Di sisi lain, Indonesia menduduki keunggulan kompetitif terbaik dibandingkan dengan kedua negara pesaingnya baik terhadap negara tujuan utama maupun terhadap dunia. Faktor-faktor yang dapat memengaruhi aliran volume ekspor adalah jarak ekonomi, gross domestic product (GDP), nilai tukar, populasi dan harga produk ekspor tersebut.

Hasil penelitian yang dilakukan oleh Pradipta dan Firdaus (2014) tentang posisi dayasaing dan faktor-faktor yang memengaruhi ekspor buahbuahan Indonesia periode 2003 sampai 2012. Komoditas yang digunakan dalam penelitian ini adalah mangga, manggis, rambutan, pisang dan melon dan metode yang digunakan dalam penelitian ini adalah gravity model, RCA dan EPD. Pada metode Export Product Dynamic (EPD) dan Revealed Comparative Advantage (RCA) menunjukkan bahwa buah yang memiliki keunggulan komparatif dan kompetitif tertinggi dinegara tujuan dan dunia adalah buah manggis, mangga, dan jambu. Ekspor buah Indonesia yang kehilangan kesempatan dalam bersaing di negara tujuan adalah stroberi. Faktor-faktor yang memengaruhi aliran ekspor buah Indonesia ke negara tujuan antara lain harga ekspor, populasi, jarak ekonomi, GDP riil dan perkapita, nilai tukar riil, indeks harga konsumen Indonesia, dan variabel dummy krisis yang terjadi di Eropa.

Penelitian yang dilakukan oleh Waristi (2014) berjudul pengaruh agama dan kebudayaan terhadap perdagangan bilateral Indonesia dengan negara anggota ASEAN menggunakan metode gravity model. Variabel yang digunakan dalam penelitian ini adalah GDP riil Indonesia, GDP riil negaara ASEAN, variabel jarak, variabel tarif, agama dan faktor kebudayaan. Hasil penelitian menunjukkan bahwa variabel jarak berkorelasi positif terhadap perdagangan. Dalam teori perdagangan bilateral, semakin jauh jarak geografi maka intensitas perdagangan akan semakin rendah dan hasil yang didapat studi ini cenderung berkorelasi positif, artinya semakin jauh jarak maka perdagangan akan meningkat.

Penelitian oleh Zahro (2013) berjudul analisis dayasaing dan faktor-faktor yang memengaruhi aliran ekspor alas kaki Indonesia di kawasan ASEAN dan China periode 2000 sampai 2011. Metode yang digunakan dalam penelitian ini adalah gravity model dan Revealed Comparative Advantage (RCA). Variabel yang digunakan adalah GDP Indonesia, GDP negara tujuan, jarak ekonomi, nilai tukar riil serta dummy pemberlakuan ACFTA. Nilai RCA menunjukkan bahwa produk alas kaki Indonesia berdayasaing tinggi baik di pasar Asia Tenggara maupun pasar dunia. Aliran ekspor alas kaki Indonesia dipengaruhi oleh GDP riil Indonesia dan GDP nominal negara tujuan dan nilai tukar riil.

Penelitian yang dilakukan oleh Hanoum (2016) berjudul analisis kinerja ekspor elektronika Indonesia ke Amerika Latin. Data yang digunakan dalam penelitian ini adalah data tahunan 2009 sampai 2013. Metode analisis yag digunakan adalah RCA, porter's diamond, EPD dan gravity model. Hasil estimasi gravity model menunjukkan bahwa variabel independen yang signifikan memengaruhi nilai ekspor elektronika ke Amerika Latin adalah GDP perkapita Indonesia, jarak ekonomi, harga ekspor, GDO perkapita negara tujuan, dan populasi. Sedangkan variabel REER tidak signifikan. Hasil penelitian juga menunjukkan bahwa elektronik Indonesia memiliki dayasaing komparatif tetapi dayasaing kompetitif masih lemah.

\section{Kerangka Pemikiran}

Alas kaki merupakan produk unggulan ekspor Indonesia. Indonesia harus mencari pasar baru selain Amerika dan Eropa yang pernah terkena 
krisis dan dapat memengaruhi ekspor Indonesia. Salah satu tujuan kawasan yang dapat dijadikan peluang besar bagi Indonesia untuk melakukan ekspor adalah kawasan Asia. Adanya kesepakatan diantara kawasan Asia salah satunya ASEAN membuat adanya kesempatan bagi Indonesia untuk memperluas pangsa ekspornya ke kawasan ASEAN. Negara ASEAN yang menjadi negara tujuan utama alas kaki Indonesia diantaranya Singapura.

Berdasarkan hal tersebut, maka tujuan dari penelitian ini adalah untuk menganalisis dayasaing komoditi ekspor alas kaki Indonesia di kawasan ASEAN dengan menghitung nilai RCA. Selanjutnya untuk dapat menganalisis faktorfaktor yang memengaruhi aliran ekspor alas kaki Indonesia ke ASEAN maka digunakan metode gravity model. Analisis dayasaing yang digunakan adalah analisis RCA (Revealed Comparative Advantages) dan porter's diamond model. Analisis EPD digunakan untuk melihat dinamika ekspor alas kaki Indonesia di kawasan ASEAN. Keempat analisis ini dapat digunakan untuk melihat bagaimana kinerja ekspor alas kaki Indonesia ke ASEAN.

\section{METODE}

\section{Jenis dan Sumber Data}

Jenis data yang digunakan dalam penelitian ini merupakan data sekunder yang diperoleh dari beberapa sumber diantaranya Uncomtrade dan WITS (World Integrated Trade Solution) (nilai dan volume ekspor), Centre d'Etudes Prospectives et d'Informations Internatinales (CEPII) (Jarak Negara), World Bank (Pertumbuhan GDP perkapita), UNCTAD (REER).

\section{Metode Analisis}

Metode analisis yang digunakan dalam penelitian ini yaitu metode kuantitatif dan kualitatif. Pengolahan kuantitatif menggunakan analisis regresi berganda dengan menggunakan Gravity Model. Pemilihan model panel data dilakukan karena dapat menyediakan informasi yang banyak untuk perkembangan estimasi dan hasil teori. Sementara untuk menganalisis dayasaing dilakukan dengan analisis Revealed Comparative Advantages (RCA) dan analisis dinamika ekspor menggunakan Export Product
Dynamic (EPD). Untuk analisis dayasaing kompetitif menggunakan porter's diamond. Data diolah menggunakan Eviews 8.0 dan Microsoft Excel 2010.

\section{Analisis Revealed Comparative Advantages (RCA)}

Konsep RCA diperkenalkan oleh Ballasa tahun 1965, yang menganggap bahwa keunggulan komparatif suatu negara dicerminkan dalam ekspornya. Model RCA menunjukkan keunggulan komparatif yang dimiliki oleh suatu wilayah. Dengan menggunakan analisis RCA maka posisi dayasaing alas kaki Indonesia di kawasan ASEAN dapat diketahui. Adapun variabel yang diukur adalah kinerja ekspor suatu produk terhadap total ekspor suatu wilayah yang kemudian dibandingkan dengan pangsa nilai produk dalam perdagangan dunia. RCA dapat dihitung melalui:

Dimana:

$$
\operatorname{RCA}_{\mathrm{ij}}=\frac{X i j / X}{W i j / W}
$$

$\mathrm{RCA}_{\mathrm{ij}}=$ Tingkat dayasaing komoditi alas kaki Indonesia di negara $j$

$\mathrm{X}_{\mathrm{ij}}=$ Nilai ekspor Indonesia komoditi alas kaki ke negara $\mathrm{j}$ (US\$)

$\mathrm{X}=$ Nilai total ekspor Indonesia ke negara $\mathrm{j}$ (US\$)

$\mathrm{W}_{\mathrm{j}}=$ Nilai ekspor dunia komoditi alas kaki ke negara $\mathrm{j}$ (US\$)

$\mathrm{W}=$ Nilai total ekspor dunia ke negara $\mathrm{j}$ (US\$)

$=$ Tahun ke- $\mathrm{t}$

$=$ Negara asal

Jika nilai RCA lebih dari satu, maka negara tersebut memiliki keunggulan komparatif dalam komoditi yang diekspor. Sedangkan jika nilai RCA kurang dari satu maka negara tersebut tidak memiliki keungulan komparatif dalam komoditi yang diekspor.

\section{Analisis EPD (Export Product Dynamic)}

Konsep EPD menghitung apakah suatu produk yang diekspor oleh Indonesia memiliki potensi yang besar ke kawasan ASEAN. Rumus untuk menghitung kelemahan dana kekuatan 
produk dalam analisis EPD adalah sebagai berikut:

Sumbu X : Pertumbuhan pangsa pasar ekspor Indonesia

Sumbu $X=\frac{\sum_{t=1}^{T}\left(\left(\frac{X i}{X t}\right) t \times 100 \%-\left(\frac{X i}{X t}\right) t-1 \times 100 \%\right)}{T}$

Sumbu Y : Pertumbuhan pangsa pasar Indonesia di kawasan ASEAN

Sumbu Y $=\frac{\sum_{t=1}^{T}\left(\left(\frac{W i}{W t}\right) t \times 100 \%-\left(\frac{W i}{W t}\right) t-1 \times 100 \%\right)}{T}$

Dimana:

$\mathrm{X}_{\mathrm{i}}=$ Nilai ekspor komoditi alas kaki Indonesia ke ASEAN (US\$)

$\mathrm{X}_{\mathrm{t}}=$ Nilai ekspor komoditi alas kaki dunia ke ASEAN (US\$)

$\mathrm{W}_{\mathrm{i}}=$ Nilai ekspor total Indonesia ke ASEAN (US\$)

$\mathrm{W}_{\mathrm{t}}=$ Nilai ekspor total dunia ke ASEAN (US\$)

$\mathrm{T}=$ Jumlah tahun

$\mathrm{t}=$ Tahun ke- $\mathrm{t}$

Matriks posisi dayasaing EPD tardiri dari rising star, lost opportunity, falling star, dan retreat. Rising Star menunjukkan adanya peningkatan pangsa pasar dan permintaan ekspor Indonesia ke negara tujuan. Lost Opportunity merupakan kondisi pasar dengan penurunan pangsa pasar ekspor yang tidak diharapkan, sehingga kehilangan kesempatan pangsa di negara tujuan. Falling Star merupakan kondisi dimana terjadi peningkatan pangsa ekspor, namun tidak diikuti oleh peningkatan permintaan terhadap komoditi tersebut. Retreat merupakan kondisi dimana produk suatu negara sudah tidak diinginkan lagi oleh pangsa pasar, sehingga terjadi penurunan pangsa ekspor dan permintaan produk yang negatif.

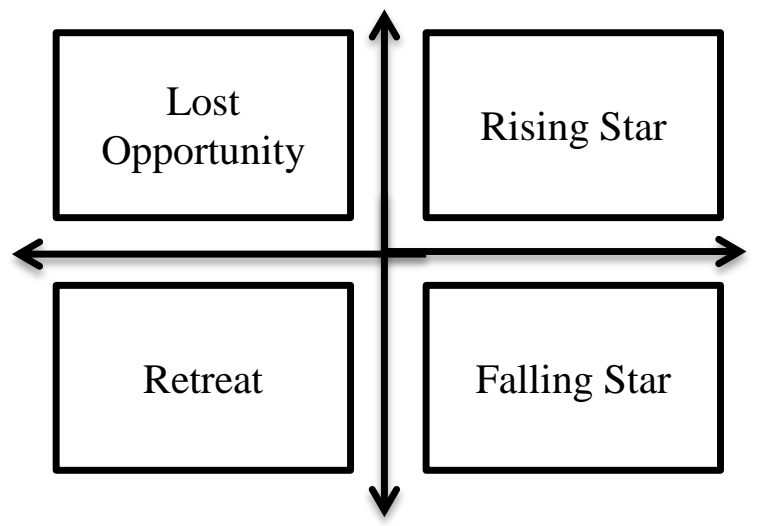

Gambar 6. Matriks Dayasaing EPD

Analisis Gravity Model dengan Data Panel. Data panel merupakan gabungan antara data time series dan cross section. Panel data memiliki jarak yang sama dengan dimensi waktu. Menurut Baltagi (2005) dalam Gujarati (2009), ada beberapa keuntungan dari menggunakan panel data, antara lain:

1. Panel data dapat mengatur heterogenitas individual

2. Panel data memberikan informasi data yang lebih informatif, lebih beragam, kolinieritas rendah antar sesama variabel, lebih banyak derajat bebas, dan lebih efisien.
3. Panel data lebih baik dalam mempelajari dynamics of adjustment.

4. Panel data lebih baik dalam mengidentifikasi dan mengukur dampak yang sederhana tapi tidak dapat dideteksi dalam pure cross-section atau pure time-series.

5. Model panel data mengizinkan para penelitinya untuk membangun dan menguji perilaku model yang lebih rumit dari pada purely crosssection atau time-series.

6. Panel data dapat meminimisasi hasil yang bias jika kita menjumlahkan individu-individu atau perusahaan pada jumlah yang besar. 
Estimasi Model. Estimasi model dalam gravity model ada tiga model yaitu model pooled least square (PLS), fixed effect model (FEM) dan random effect model (REM).

Model Pooled Least Square (PLS). Pendekatan ini menggunakan gabungan dari seluruh data sehingga akan terdapat NxT observasi, dimana N merupakan jumlah unit cross section dan $\mathrm{T}$ merupakan jumlah series yang digunakan (Firdaus, 2011). Kelemahan dari pendekatan ini adalah dugaan parameter $\beta$ akan bias yang disebabkan karena PLS tidak dapat membedakan obserasi yang berbeda pada periode yang sama, atau tidak dapat membedakan observasi yang sama pada periode yang berbeda.

Fixed Effect Model (FEM). FEM muncul ketika antara efek individu dan peubah penjelas memiliki korelasi dengan $X_{\text {it }}$ atau memiliki pola yang sifatnya tidak acak. Asumsi ini membuat komponen error dari efek individu dan waktu dapat menjadi bagian dari intersep, yaitu:

Untuk one way komponen error:

$$
\mathrm{y}_{\mathrm{it}}=\alpha_{\mathrm{i}+} \lambda_{\mathrm{i}}+\mathrm{X}_{\mathrm{it}} \beta+\mathrm{u}_{\mathrm{it}}
$$

Untuk two way eror component:

$$
\mathrm{y}_{\mathrm{it}}=\alpha_{\mathrm{i}+} \lambda_{\mathrm{i}}+\mu_{\mathrm{t}}+\mathrm{X}_{\mathrm{it}} \beta+\mathrm{u}_{\mathrm{it}}
$$

Random Effects Model (REM). REM muncul ketika antara efek individu dan regresor tidak ada korelasi. Asumsi ini membuat komponen error dari efek individu dan waktu dimasukkan kedalam error.

Untuk one way error component:

$$
\mathrm{y}_{\mathrm{it}}=\alpha_{\mathrm{i}+} \lambda_{\mathrm{i}}+\mathrm{X}_{\mathrm{it}} \beta+\mathrm{u}_{\mathrm{it}}
$$

Untuk two way error component:

$$
\mathrm{y}_{\mathrm{it}}=\alpha_{\mathrm{i}+} \mathrm{X}_{\mathrm{it}} \beta+\mathrm{u}_{\mathrm{it}}+\lambda_{\mathrm{i}}+\mu_{\mathrm{t}}
$$

Asumsi yang paling penting dikaitkan dalam REM adalah nilai harapan dari $x_{i t}$ untuk setiap $\lambda_{i}$ adalah 0 , atau $\mathrm{E}\left(\lambda_{\mathrm{i}}, \mathrm{x}_{\mathrm{it}}\right)=0$.

\section{Pemilihan Model}

Pemilihan model yang digunakan dalam sebuah penelitian perlu dilakukan berdasarkan pertimbangan statistik. Hal ini ditujukan untuk memperoleh dugaan yang efisien. Pendekatan terbaik dalam metode data panel ada dua, yakni menggunakan Uji Chow (Chow Test) dan Uji Hausman (Hausman Test).

Chow Test. Chow test atau yang biasa disebut pengujian $\mathrm{F}$ statistik adalah pengujian untuk memilih apakah model yang terbaik menggunakan model Pooled Least Square atau Fixed Effect. Pengujian ini dilakukan dengan hipotesa sebagai berikut:

\section{$\mathrm{H}_{0}=$ Model Pooled Least Square \\ $\mathrm{H}_{1}=$ Model Fixed Effect}

Dasar penolakan terhadap Hipotesa $\mathrm{Nol}\left(\mathrm{H}_{0}\right)$ adalah dengan melihat nilai probabilitas. Jika nilai probabiitas $<(\alpha)$ maka model yang digunakan adalah model pooled least square, dan jika nilai probabilitas $>(\alpha)$ maka model yang paling baik digunakan adalah model random effect.

Hausman Test. Hausman test adalah pengujian statistik sebagai dasar pertimbangan dalam memilih untuk menggunakan model fixed effect atau model random effect. Hausmann test dilakukan dengan hipotesa sebagai berikut:

$$
\begin{aligned}
& \mathrm{H}_{0}=\text { Model Random Effect } \\
& \mathrm{H}_{1}=\text { Model Fixed Effect }
\end{aligned}
$$

Dasar untuk penolakan $\mathrm{H}_{0}$ yang digunakan dalam statistik Hausman yaitu jika nilai probabiitas $<(\alpha)$ maka model yang digunakan adalah model fixed effect, dan jika nilai probabilitas $>(\alpha)$ maka model yang paling baik digunakan adalah model random effect.

\section{Uji Kesesuaian Model}

Terdapat beberapa upaya agar dapat menghasilkan model yang konsisten, sesuai dan efisien, maka diperlukan evaluasi hasil estimasi terhadap model regresi. Kita dapat mengetahui apakah model tersebut memiliki masalah normalitas, multikolinieritas, heteroskedastisitas, dan autokorelasi.

Normalitas. Uji normalitas dilakukan untuk menunjukkan apakah error term menyebar secara normal atau tidak. Cara melakukan uji normalitas 
ini dengan melihat nilai probabilitas dan nilai Jaque-Bera yang dihasilkan. Jika nilai probabilitas dan Jaque-Bera lebih besar dari taraf nyata $(\alpha)$ sebesar 0,05 maka model telah menyebar normal.

\section{Multikolinearitas.}

Multikolinearitas menimbulkan estimator OLS mempunyai varians dan kovarians yang besar dan interval kepercayaan akan cenderung sangat lebar, banyak koefisien yang tidak signifikan dan nilai $\mathrm{R}^{2}$ yang tinggi. Cara melakukan uji multikolinearitas dengan melihat nilai spearman's rho correlation. Apabila nilai korelasi lebih kecil dari 0,8 maka model telah terbebas dari masalah multikolinearitas.

Heteroskedastisitas. Asumsi yang penting dalam classical linear regression model (CLRM) adalah faktor gangguan $\mathrm{u}_{\mathrm{i}}$ yang muncul pada FRP (fungsi regresi populasi) bersifat homoskedastik, hal ini berarti bahwa mereka semua memiliki varians yang sama. Heteroskedastisitas dapat muncul akibat adanya pencilan dalam suatu data dan kemiringan dalam distribusi satu atau lebih regresor pada model (skewnees) (Gujarati dan Porter 2009).

Autokorelasi. Uji autokorelasi dilakukan dengan membandingkan statistik Durbin Watson (DW) hasil estimasi dengan DW tabel. Jika nilai DW berada pada area non autokorelasi mendekati dua maka dapat disimpulkan bahwa model tersebut bebas dari masalah autokrelasi. Penentuan apakah model kita memiliki autokorelasi dapat ditentukan dengan aturan pada Tabel 3.

Tabel 3. Uji d Durbin Watson

\begin{tabular}{cl}
\hline \multicolumn{1}{c}{ Jika } & \multicolumn{1}{c}{ Kesimpulan } \\
\hline $0.0000<\mathrm{d}<1.0706$ & autokorelasi positif \\
$1.0706<\mathrm{d}<1.8326$ & tidak ada keputusan \\
$1.8326<\mathrm{d}<2.1674$ & tidak ada autokorelasi positif atau negative \\
$2.1674<\mathrm{d}<2.9294$ & tidak ada keputusan \\
$2.9294<\mathrm{d}<4.0000$ & autokorelasi negative \\
\hline
\end{tabular}

\section{Model Penelitian}

Berdasarkan hipotesis dan studi empiris yang disesuaikan dengan fakta di beberapa negara serta berbagai alternatif spesifikasi model yang telah dicoba dengan tetap mempertimbangkan berbagai asumsi yang menjadi acuan dalam model data panel, maka variabel yang diduga memengaruhi aliran ekspor alas kaki Indonesia adalah pertumbuhan GDP perkapita Indonesia, pertumbuhan GDP perkapita negara tujuan, nilai tukar riil rupiah terhadap dolar, jarak ekonomi antara Indonesia dan negara tujuan serta harga ekspor alas kaki Indonesia. Variabel-variabel yang akan diteliti tersebut apabila dinyatakan dalam persamaan maka akan menjadi:

$$
\begin{aligned}
& \mu_{\mathrm{it}} \quad=\text { error term } \\
& \operatorname{LNEX}_{\mathrm{it}}=\alpha+\beta_{1} \operatorname{GDPCAP}_{\mathrm{jt}}+\beta_{2} \operatorname{GDPCAP}_{\mathrm{jt}}+\beta_{3} \alpha \quad=\text { Intersep } \\
& \mathrm{LNJE}_{\mathrm{it}}+\beta_{4} \mathrm{LNREER}_{\mathrm{it}}+\beta_{5} \mathrm{LNPE}_{\mathrm{it}}+\beta=\text { Slope } \\
& \mu_{\mathrm{it}}
\end{aligned}
$$

Dimana:

EX $_{\mathrm{it}}=$ Nilai ekspor alas kaki Indonesia ke negara tujuan tahun ke-t (US\$)

GDPCAP $_{\text {it }}=$ Pertumbuhan GDP perkapita Indonesia pada tahun $\mathrm{t}$ (persen)

GDPCAP $_{\mathrm{t}} \quad=$ Pertumbuhan GDP perkapita negara tujuan pada tahun $\mathrm{t}$ (persen)

$\mathrm{JE}_{\mathrm{it}}=$ Jarak ekonomi antar Indonesia dengan negara tujuan (KM)

REER $_{\mathrm{it}}=$ Real effective exchange rate (mata uang negara tujuan / US\$)

$\mathrm{PE}_{\mathrm{it}} \quad=$ Harga ekspor alas kaki Indonesia (US\$) 


\section{HASIL DAN PEMBAHASAN}

\section{Gambaran Umum Alas Kaki Indonesia}

Alas kaki merupakan komoditi ekspor unggulan Indonesia serta termasuk ke sektor unggulan dalam industri manufaktur. Industri alas kaki juga termasuk industri yang bersifat padat karya sehingga menyerap tenaga kerja yang besar. Dari sisi lapangan kerja, industri ini mampu menyerap tenaga kerja sebanyak 643 ribu orang yang setara dengan 4.21 persen dari tenaga kerja industri manufaktur. Pada tahun 2014, pangsa pasar alas kaki Indonesia di pasar dunia sebesar 2.85 persen dan termasuk dalam peringkat enam besar pengekspor alas kaki setelah China, Italia, Vietnam, Jerman dan Belgia. Hal ini menunjukkan bahwa industri alas kaki mempunyai peluang untuk meningkatkan ekspor (Kemenperin 2014).

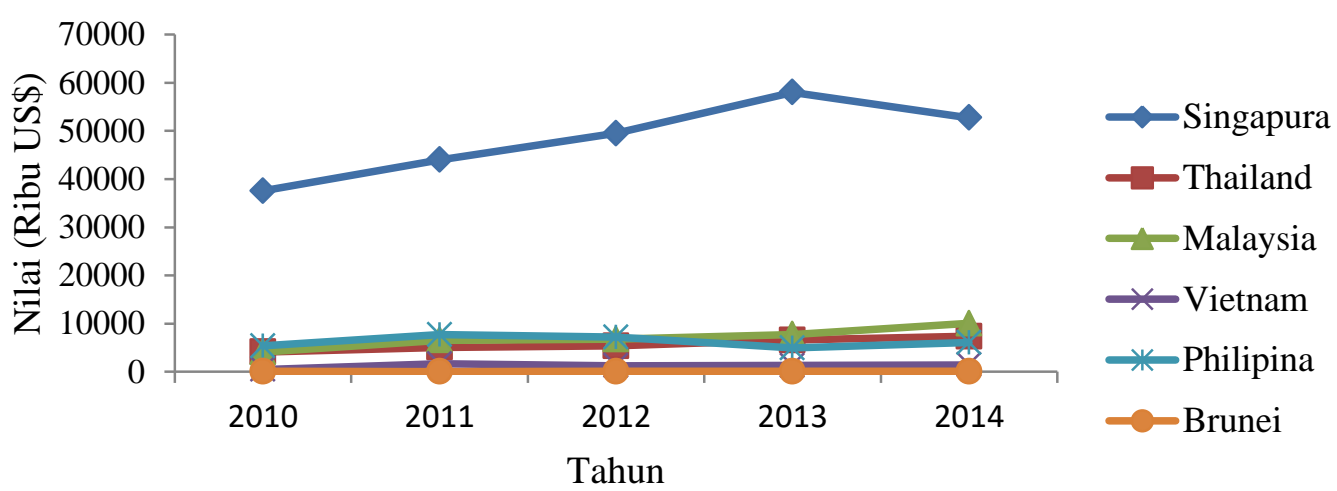

\section{Sumber : UNCOMTRADE 2017}

Gambar 7. Nilai Ekspor Alas Kaki Indonesia Tahun 2010-2014 (Ribu US\$)

Nilai ekspor alas kaki Indonesia tahun 2010 sampai 2014 di enam negara kawasan ASEAN berfluktuatif, namun nilainya cenderung meningkat (Gambar 7). Hal ini mengindikasikan bahwa ekspor alas kaki Indonesia diminati di keenam negara tersebut. Namun, Indonesia harus mampu meningkatkan dayasaing agar dapat bertahan di pasar Internasional khususnya kawasan ASEAN. Singapura merupakan negara dengan nilai ekspor alas kaki terbesar dibandingkan lima negara lainnya. Kemudian diikuti oleh negara Filipina, Malaysia, Thailand, Vietnam dan Brunei. Hal ini dikarenakan Singapura termasuk ke dalam negara tujuan utama ekspor alas kaki Indonesia. Oleh karena itu, Indonesia perlu meningkatkan efisiensi dan menciptakan inovasi di bidang alas kaki agar mampu meningkatkan dayasaing di lima negara ASEAN lainnya.

\section{Gambaran Umum Negara Tujuan}

Ekspor sub sektor industri merupakan sub sektor yang berperan penting dalam nilai ekspor Indonesia. Salah satu komoditas unggulan industri adalah alas kaki. Penelitian ini fokus pada ekspor komoditi alas kaki (HS 6403). Nilai ekspor alas kaki cenderung meningkat setiap tahun di pasar tujuan utama seperti Amerika Serikat dan Eropa. Nilai ekspor alas kaki di kedua negara tersebut cenderung lebih tinggi dibanding nilai ekspor alas kaki di kawasan yang lebih dekat dengan Indonesia yaitu ASEAN, sehingga Indonesia harus dapat meningkatkan dayasaing produk agar dapat diterima di kawasan ASEAN

Jumlah populasi di kawasan ASEAN terus meningkat setiap tahunnya (Tabel 4) mengindikasikan bahwa pangsa pasar di kawasan ASEAN cukup besar. Filipina merupakan negara yang menjanjikan bagi Indonesia dalam upaya peningkatan alas kaki Indonesia karena mempunyai populasi yang cukup besar. Kemudian diikuti oleh negara Vietnam, Thailand, Malaysia dan Singapura. Brunei merupakan negara dengan populasi dalam jumlah paling kecil. Selain itu, dengan banyaknya kesepakatan bersama yang telah dibentuk di kawasan ASEAN membuat Indonesia berpotensi untuk meningkatkan ekspornya di kawasan ASEAN. 
Tabel 4. Populasi Negara Kawasan ASEAN Tahun 2010 - 2014 (Ribu jiwa)

\begin{tabular}{lrrrrr}
\hline Negara & $\mathbf{2 0 1 0}$ & \multicolumn{1}{c}{$\mathbf{2 0 1 1}$} & $\mathbf{2 0 1 2}$ & $\mathbf{2 0 1 3}$ & \multicolumn{1}{c}{$\mathbf{2 0 1 4}$} \\
\hline Singapura & 5079.0 & 5190.7 & 5299.5 & 5405.0 & 5506.6 \\
Thailand & 66692.0 & 66903.0 & 67164.1 & 67451.4 & 67726.0 \\
Vietnam & 88357.8 & 89321.9 & 90335.5 & 91378.8 & 92423.3 \\
Filipina & 93038.9 & 94501.2 & 96017.3 & 97571.7 & 99138.7 \\
Malaysia & 28119.5 & 28573.0 & 29021.9 & 29465.4 & 29902.0 \\
Brunei D & 393.3 & 399.4 & 405.5 & 411.5 & 417.4 \\
\hline UNCTAD 2017 & & & & &
\end{tabular}

Nilai tukar riil negara tujuan ekspor alas kaki Indonesia terhadap US\$ tahun 2010 sampai 2014 ditunjukkan oleh Tabel 5. Nilai tukar riil negara tujuan terhadap US\$ cenderung fluktuatif. Ketika nilai tukar negara tujuan menguat (apresiasi) maka akan mengakibatkan produk dalam negeri lebih mahal daripada produk luar negeri sehingga negara tujuan akan cenderung melakukan ekspor. Sebaliknya, ketika nilai tukar negara tujuan melemah (depresiasi) maka negara tujuan akan mengurangi ekspor akibat masyarakat domestik lebih menyukai barang dalam negeri. Vietnam merupakan satu-satunya negara dengan nilai tukar yang menguat (apresiasi) tahun 2010 sampai 2014. Sehingga ekspor alas kaki Indonesia ke Vietnam berpotensi untuk bernilai tinggi.

Tabel 5. Nilai Tukar Riil Negara Tujuan terhadap US\$ Tahun 2010-2014 (Mata Uang Negara Tujuan /US\$)

\begin{tabular}{lrrrrr}
\hline Negara & $\mathbf{2 0 1 0}$ & $\mathbf{2 0 1 1}$ & $\mathbf{2 0 1 2}$ & $\mathbf{2 0 1 3}$ & $\mathbf{2 0 1 4}$ \\
\hline Singapura & 1.36 & 1.23 & 1.20 & 1.19 & 1.21 \\
Thailand & 31.69 & 30.30 & 30.60 & 30.04 & 31.67 \\
Malaysia & 3.22 & 3.06 & 3.10 & 3.14 & 3.22 \\
Vietnam & 18612.92 & 17827.58 & 16938.46 & 16205.21 & 15983.79 \\
Filipina & 45.11 & 42.70 & 41.18 & 40.78 & 41.63 \\
Brunei & 1.36 & 1.27 & 1.28 & 1.30 & 1.34 \\
\hline
\end{tabular}

Sumber : World Bank (diolah) 2017

GDP suatu negara dapat mengindikasikan bahwa negara tersebut memiliki potensi besar dalam perluasan pangsa pasar perdagangan suatu negara. Gambar 8 menunjukkan GDP perkapita di enam negara kawasan ASEAN tahun 2010 sampai 2014. GDP perkapita untuk enam negara di kawasan ASEAN tersebut cenderung meningkat setiap tahunnya. Brunei merupakan negara dengan rata-rata pertumbuhan paling tinggi dibanding lima negara lainnya yaitu sebesar 5.31 persen. Kemudian Vietnam sebesar 4.59 persen, Filipina sebesar 4.23 persen,
Malaysia 3.76 persen, Singapura sebesar 2.52 persen dan rata-rata pertumbuhan GDP perkapita terendah yaitu Thailand sebesar 2.5 persen. GDP yang terus meningkat dapat menjadi pasar yang potensial bagi Indonesia agar dapat meningkatkan ekspor di kawasan ASEAN. GDP dan populasi yang cenderung meningkat setiap tahunnya di enam negara dapat menjadi acuan bagi Indonesia untuk terus berusaha meningkatkan nilai ekspor dan dayasaing produk guna meningkatkan pertumbuhan ekonomi (Hanoum 2016). 


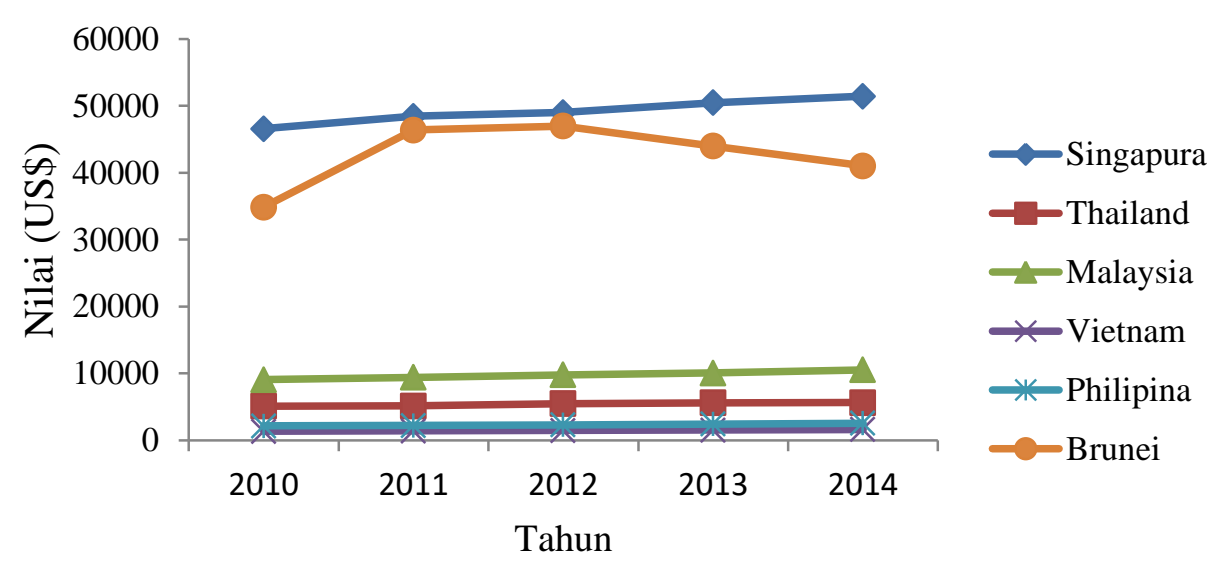

Sumber: World Bank 2017

Gambar 8. GDP Perkapita Negara Tujuan Tahun 2010-2014 (US\$)

\section{Daya saing Komparatif Alas kaki Indonesia ke ASEAN Periode 2010-2014}

\section{Revealed Comparative Advantages (RCA)}

Ekspor komoditi alas kaki Indonesia ke kawasan ASEAN cenderung meningkat setiap tahun. Namun nilai ekspor tersebut masih terbilang rendah apabila dibandingkan ekspor alas kaki Indoensia ke negara Eropa. Oleh karena itu diperlukan penelitian lebih lanjut untuk melihat seberapa besar dayasaing alas kaki Indonesia di kawasan ASEAN dengan menggunakan analisis Revealed Comparative Advantages (RCA). Hasil analisis dayasaing komparatif komoditi alas kaki Indonesia mempunyai nilai RCA yang dapat dilihat pada Tabel 6.

Hasil perhitungan dengan analisis RCA menunjukkan bahwa alas kaki Indonesia rata-rata memiliki nilai RCA lebih dari satu kecuali di negara Malaysia. Hal ini dapat terjadi salah satunya disebabkan karena Indonesia dan
Malaysia memiliki jenis sumber daya alam yang secara umum sama. Selain itu, saat ini industri alas kaki di Malaysia bukan lagi dikategorikan sebagai industri saja, namun industri sepatu disana berubah menjadi industri pariwisata dan ekonomi kreatif. Contohnya merek sepatu Charles And Keith buatan Malaysia, yang saat ini diminati dunia. Hal ini berbeda dengan negara Indonesia yang masih menggolongkan semua bidang sebagai industri yang konservatif. Nilai RCA tertinggi selama periode 2010 sampai 2014 adalah Singapura sebesar 3.523 pada tahun 2010 . Rata-rata nilai RCA juga cenderung memiliki nilai lebih besar dari satu. Kondisi ini mengindikasikan bahwa komoditi alas kaki Indonesia memiliki dayasaing komparatif di kawasan ASEAN. Singapura memiliki nilai ratarata RCA lebih tinggi dibandingkan negara lainnya, kemudian disusul oleh Vietnam, Filipina, Thailand, Malaysia dan Brunei Darussalam.

Tabel 6. Hasil RCA komoditas alas kaki Indonesia

\begin{tabular}{lccccccc}
\hline Negara & $\mathbf{2 0 1 0}$ & $\mathbf{2 0 1 1}$ & $\mathbf{2 0 1 2}$ & $\mathbf{2 0 1 3}$ & $\mathbf{2 0 1 4}$ & $\begin{array}{c}\text { Rata- } \\
\text { rata } \\
\text { RCA }\end{array}$ & $\begin{array}{c}\text { Rata-rata } \\
\text { Pertumbuhan } \\
\text { RCA }\end{array}$ \\
\hline Singapura & 3.523 & 2.894 & 3.384 & 3.426 & 3.069 & 3.259 & -2.525 \\
Thailand & 1.376 & 1.037 & 2.144 & 2.265 & 2.175 & 1.799 & 20.945 \\
Malaysia & 0.555 & 1.025 & 1.051 & 0.838 & 0.983 & 0.89 & 21.064 \\
Vietnam & 1.543 & 3.425 & 2.22 & 3.005 & 3.094 & 2.657 & 31.277 \\
Filipina & 1.944 & 2.09 & 2.105 & 1.411 & 1.567 & 1.823 & -3.421 \\
Brunei D & 1.346 & 1.508 & 1.09 & 0.476 & 0.614 & 1.007 & -10.755 \\
\hline
\end{tabular}


Thailand dan Vietnam merupakan negara yang memiliki rata-rata pertumbuhan RCA benilai positif yang mengindikasikan bahwa dayasaing ekspor alas kaki Indonesia meningkat bagi kedua negara tersebut. Untuk negara Malaysia, meskipun alas kaki Indonesia tidak berdayasaing namun nilai dayasaing alas kaki Indonesia terus meningkat di negara tersebut. Sedangkan Singapura, Filipina dan Brunei merupakan negara dengan pertumbuhan rata-rata RCA yang bernilai negatif. Hal ini menunjukkan bahwa dayasaing ekspor alas kaki di ketiga negara tersebut menurun. Salah satu faktor penyebab terjadinya hal tersebut karena ada pesaing produk alas kaki dari negara lain yaitu Vietnam. Upah tenaga kerja indonesia yang cenderung tinggi mengakibatkan peningkatan biaya produksi alas kaki Indonesia sehingga alas kaki Indonesia kalah bersaing dengan alas kaki Vietnam.

\section{Dinamika Dayasaing Ekspor Alas Kaki Indonesia ke Kawasan ASEAN Periode 2010 - 2014}

Hasil scatter plot analisis EPD komoditi alas kaki Indonesia ke kawasan ASEAN ditunjukkan oleh Gambar 9. Negara-negara yang berada pada posisi rising star adalah Thailand. Hal ini mengindikasikan bahwa terjadi peningkatan pangsa pasar dan permintaan ekspor alas kaki Indonesia di negara tersebut. Negara Malaysia, Singapura dan Vietnam berada pada posisi falling star menunjukkan bahwa pangsa pasar ekspor komoditi alas kaki tetap meningkat, namun permintaan terhadap komoditi alas kaki justru menurun. Kondisi retreat dialami oleh Filipina yang menunjukkan bahwa adanya penurunan pangsa pasar ekspor alas kaki Indonesia di Filipina diikuti dengan penurunan permintaan terhadap komoditi alas kaki.

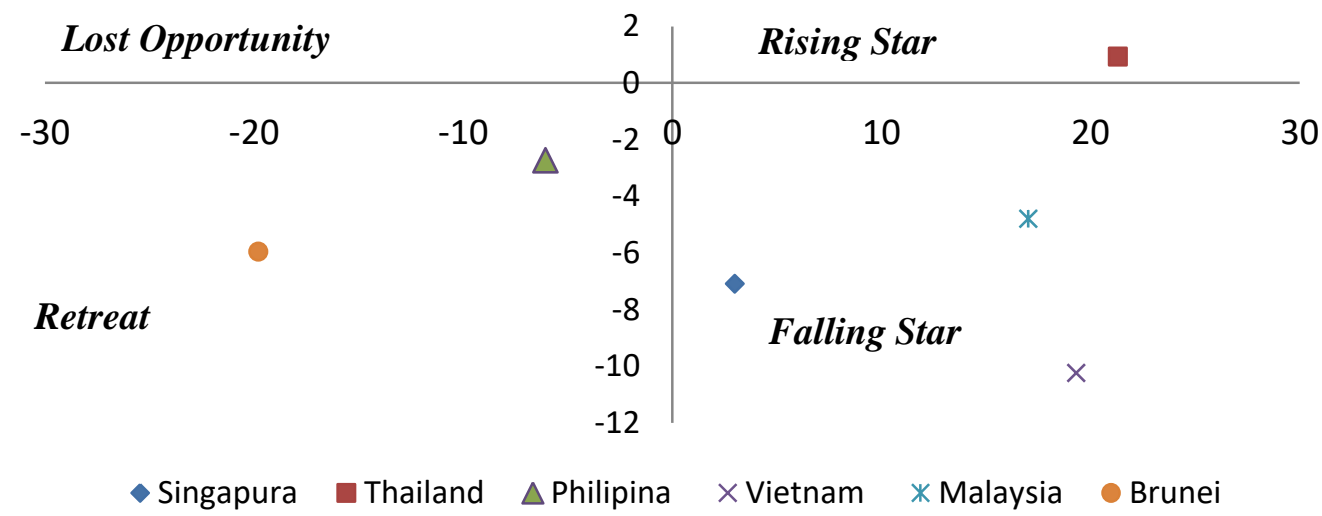

Gambar 9. Hasil EPD Alas Kaki Indonesia di Kawasan ASEAN

Thailand merupakan satu-satunya negara yang berada pada posisi rising star dan berdayasaing (Tabel 7), hal ini berarti Indonesia masih mempunyai kesempatan untuk memperuluas pangsa pasar dan harus mempertahankan nilai ekspor alas kaki di negara Thailand. Untuk Vietnam dan Singapura, alas kaki Indonesia berdayasaing dan mengalami peningkatan pangsa pasar namun penurunan permintaan alas kaki. Hal ini dapat terjadi karena Vietnam merupakan negara pengekspor alas kaki ketiga terbesar di dunia dan untuk transaksi perdagangan Indonesia-Singapura, penetrasi pasar produk industri ke negara tersebut kurang dapat mencerminkan peluang pasar bagi Indonesia di negara tetangga itu. Selain karena ukuran populasi yang kecil, Singapura hanya sering digunakan sebagai tempat transit produk ekspor Indonesia yang ingin mendapat kapal ke tujuan ekspor negara lain. Malaysia juga mengalami peningkatan pangsa pasar dan penurunan permintaan ekspor alas kaki namun alas kaki Indonesia tidak berdayasaing. Ekspor alas kaki Indonesia berpotensi untuk mengalami peningkatan karena pangsa pasar untuk Vietnam, Singapura dan Malaysia mengalami peningkatan. Strategi yang dapat dilakukan diantaranya menciptakan inovasi teknologi alas kaki sehingga menghasilkan efisiensi produk, meningkatkan kualitas produk alas kaki dan melakukan pengembangan branding alas kaki nasional secara nasional maupun internasional. 
Filipina dan Brunei termasuk negara yang mengalami penurunan pangsa pasar dan penurunan permintaan ekspor alas kaki namun alas kaki Indonesia di kedua negara ini masih berdayasaing. Hal ini terjadi akibat masih adanya hambatan misalnya di negara Brunei belum adanya jaringan dan fasilitas dalam bentuk persetujuan perdagangan termasuk pembahasan mengenai regulasi impor, belum adanya angkutan laut langsung dan jalur transportasi langsung untuk pengangkutan barang sehingga terjadi penurunan pangsa pasar.

Tabel 7. Kombinasi RCA dan EPD Alas Kaki Indonesia Tahun 2010-2014

\begin{tabular}{lll}
\hline Dinamika Dayasaing & Berdayasaing & Tidak Berdayasaing \\
\hline Rising Star & Thailand & \\
Falling Star & Vietnam, Singapura & Malaysia \\
Lost Opportunity & \\
Retreat & Filipina, Brunei & \\
\hline
\end{tabular}

Faktor-faktor yang Memengaruhi Ekspor Alas Kaki Indonesia ke Kawasan ASEAN

Penelitian ini menggunakan gravity model untuk dapat menjelaskan faktor-faktor yang memengaruhi nilai ekspor komoditi alas kaki Indonesia ke kawasan ASEAN. Variabel yang digunakan dalam analisis gravity model diantaranya nilai ekspor alas kaki Indonesia ke ASEAN $\left(\mathrm{EX}_{\mathrm{t}}\right)$, pertumbuhan GDP perkapita Indonesia $\left(\mathrm{GDPCAP}_{\mathrm{it}}\right)$, pertumbuhan GDP perkapita negara tujuan $\left(\mathrm{GDPCAP}_{\mathrm{jt}}\right)$, jarak ekonomi $\left(\mathrm{JE}_{\mathrm{j}}\right)$, real effective exchange rate $\left(\right.$ REER $\left._{\mathrm{jt}}\right)$ dan harga ekspor alas kaki $\left(\mathrm{PE}_{\mathrm{jt}}\right)$. Tabel 6 menunjukkan hasil estimasi gravity model untuk ekspor alas kaki Indonesia ke kawasan ASEAN dengan persamaan:

$$
\begin{aligned}
\mathrm{LNEX}_{\mathrm{it}}= & \alpha+\beta_{1} \mathrm{GDP}_{\mathrm{it}}+\beta_{2} \mathrm{GDP}_{\mathrm{jt}}+\beta_{3} \mathrm{LNJE}_{\mathrm{it}}+ \\
& \beta_{4} \mathrm{LNREER}_{\mathrm{it}}+\beta_{5} \mathrm{LNPE}_{\mathrm{it}}+\mu_{\mathrm{it}}
\end{aligned}
$$

Estimasi pemilihan model terbaik dilakukan dengan uji hausman dan uji chow untuk memilih random effect model, fixed effect model, atau pooled least square. Tabel 8 menunjukkan hasil uji estimasi model yang digunakan dalam penelitian ini.

Tabel 8. Hasil uji estimasi model

\begin{tabular}{llcc}
\hline Uji Estimasi Model & Prob. & \multicolumn{2}{c}{ Kesimpulan } \\
\hline Hausman Test & 0,0000 & Tolak $\mathrm{H}_{0}$ & FEM \\
Chow Test & 0,0131 & Tolak $\mathrm{H}_{0}$ & FEM \\
\hline
\end{tabular}

Tabel 8 memperlihatkan bahwa probabilitas uji hausman sebesar 0.0000 lebih kecil dari alpha ( $\alpha$ ) 5 persen, sehingga dapat disimpulkan bahwa cukup bukti untuk menolak $\mathrm{H}_{0}$ sehingga model yang dipilih adalah fixed effect model. Hasil uji chow menunjukkan hal yang sama untuk menolak hipotesis nol dengan nilai probabilitas sebesar 0.0131 yang lebih kecil dari alpha $(\alpha) 5$ persen. Maka model yang paling baik digunakan adalah fixed effect model.

Variabel-variabel yang signifikan memengaruhi ekspor alas kaki Indonesia ditunjukkan oleh Tabel 9. Variabel-variabel tersebut antara lain pertumbuhan GDP perkapita
Indonesia, pertumbuhan GDP perkapita negara tujuan, jarak ekonomi, real effective exchange rate (reer), dan harga ekspor alas kaki. Hasil estimasi model tersebut memiliki nilai $R$-squared sebesar 0.9993 yang menunjukkan bahwa 99.93 persen keragaman variabel dependen dapat dijelaskan oleh variabel-variabel independen dalam model. Sedangkan sebesar 0.07 persen dijelaskan oleh variabel diluar model.

Model diatas perlu untuk dilakukan pengujian asumsi klasik agar mendapatkan model yang memenuhi BLUE (Best Linear Unbiased Estimator). Uji multikolinearitas dapat dilakukan dengan membandingkan nilai probabilitas dan 
matriks korelasi antar variabel. Model nilai ekspor yang memiliki nilai $R$-squared sebesar 0.9993 dan kelima variabel yang digunakan signifikan menunjukkan bahwa model terbebas dari multikolinearitas.

Uji autokorelasi dilakukan dengan melihat nilai DW (durbin watson) sebesar 2.4475 sehingga kesimpulannya tidak ada keputusan dalam pengujian ini. Hasil uji normalitas menunjukkan bahwa nilai probabilitas sebesar 0.6940 lebih besar dari 0.05 dan nilai Jarque-Bera sebesar 0.7305 lebih besar dari 0.05 sehingga model nilai ekspor alas kaki Indonesia telah memiliki error terms yang menyebar normal. Uji heteroskedastisitas dapat melihat pada hasil Tabel 9 bahwa nilai sum square resid pada weighted statistics sebesar 0.4899 lebih kecil dari nilai sum square resid pada unweighted statistics sebesar 0.6975. Namun, karena estimasi fixed effect model telah diboboti cros section, maka masalah heteroskedastisitas dapat diabaikan.

Tabel 9. Hasil Estimasi Gravity Model Nilai Ekspor Alas Kaki Indonesia Menggunakan Fixed Effect Model dengan Pembobotan cross section

\begin{tabular}{|c|c|c|c|}
\hline Variabel & Koefisien & \multicolumn{2}{|c|}{ Prob } \\
\hline GDPCAP $_{\text {it }}$ & $-0.6152^{* * *}$ & \multicolumn{2}{|c|}{0.0000} \\
\hline $\operatorname{GDPCAP}_{\mathrm{jt}}$ & $0.0080^{* * *}$ & \multicolumn{2}{|c|}{0.0000} \\
\hline LNREER $_{\mathrm{jt}}$ & $-2.2146^{* *}$ & \multicolumn{2}{|c|}{0.0321} \\
\hline $\mathrm{LNJE}_{\mathrm{jt}}$ & $-3.2256^{* * *}$ & \multicolumn{2}{|c|}{0.0000} \\
\hline $\mathrm{LNPEX}_{\mathrm{jt}}$ & $-1.5790^{* * *}$ & \multicolumn{2}{|c|}{0.0000} \\
\hline $\mathrm{C}$ & $31.6533^{* * *}$ & \multicolumn{2}{|c|}{0.0000} \\
\hline Statistics & & Weighted & unweighted \\
\hline R-squared & & 0.9993 & 0.9925 \\
\hline Prob (F-statistic) & & 0.0000 & \\
\hline Sum squared resid & & 0.4899 & 0.6975 \\
\hline Durbin-watson stat & & 2.4475 & 2.0188 \\
\hline
\end{tabular}

Keterangan: Signifikan pada taraf nyata $1 \%(* * *)$ Signifikan pada taraf nyata $5 \%(* *)$

\section{Pertumbuhan GDP Perkapita Indonesia}

Pertumbuhan GDP perkapita Indonesia merupakan representasi dari GDP perkapita Indonesia. Pertumbuhan GDP perkapita Indonesia berpegaruh signifikan dan memiliki hubungan negatif dengan nilai ekspor alas kaki Indonesia. Hasil estimasi menunjukkan bahwa kenaikan pertumbuhan GDP perkapita Indonesia sebesar 1 persen akan menurunkan nilai ekspor alas kaki Indonesia sebesar 0.6152 persen (ceteris paribus). Hasil ini sudah sesuai dengan studi Yunia (2015) bahwa ketika terjadi peningkatan GDP Indonesia maka nilai ekspor komoditi akan turun akibat peningkatan daya beli masyarakat Indonesia sehingga konsumsi dalam negeri meningkat. Koefisien sebesar $|-0.6152|<|1|$ menunjukkan bahwa elastisitas pendapatan terhadap permintaan rendah sehingga alas kaki merupakan barang inferior di negara Indonesia. Artinya ketika pendapatan meningkat maka permintaan alas kaki Indonesia menurun. Hal tersebut terjadi karena alas kaki merupakan fashion maka ketika pendapatan meningkat, masyarakat akan lebih menyukai alas kaki yang memiliki brand.

\section{Pertumbuhan GDP Perkapita Negara Tujuan}

Pertumbuhan GDP perkapita negara tujuan merupakan representasi dari GDP perkapita negara tujuan. Pertumbuhan GDP perkapita negara tujuan signifikan dan memiliki hubungan positif terhadap nilai ekspor komoditi alas kaki Indonesia ke enam negara di kawasan ASEAN. Nilai probabilitas yang didapatkan dari hasil estimasi sebesar 0.0000 dan hasil estimasi 
menunjukkan bahwa ketika terjadi peningkatan pertumbuhan GDP perkapita negara tujuan sebesar 1 persen maka akan terjadi peningkatan ekspor komoditi alas kaki Indonesia ke lima negara di kawasan ASEAN sebesar 0.0080 persen (cateris paribus). Hal ini sesuai dengan hasil penelitian yang dilakukan oleh Anhar (2016) bahwa GDP perkapita riil negara Amerika Latin memiliki hubungan positif dengan nilai ekspor tekstil dan produk tekstil Indonesia. Selain itu, hal ini juga sudah sesuai dengan teori pendapatan bahwa nilai ekspor dan pendapatan memiliki hubungan positif. Koefisien $|0.0080|<$ |1| menunjukkan bahwa alas kaki termasuk barang inferior di negara tujuan. Hal ini mengindikasikan bahwa ketika pendapatan meningkat maka masyarakat domestik lebih menyukai alas kaki yang memiliki brand karena alas kaki merupakan bidang fashion.

\section{Jarak Ekonomi}

Jarak ekonomi signifikan dan memiliki hubungan negatif dengan nilai ekspor komoditi alas kaki Indonesia ke enam negara di kawasan ASEAN. Nilai probabilitas yang didapatkan dari hasil estimasi sebesar 0.0000 dan hasil estimasi menunjukkan bahwa ketika terjadi peningkatan jarak ekonomi antar Indonesia dengan lima negara tujuan sebesar 1 persen maka akan terjadi penurunan ekspor komoditi alas kaki Indonesia ke lima negara di kawasan ASEAN sebesar 3.2256 persen (cateris paribus). Dalam teori perdagangan bilateral, semakin jauh jarak geografi maka intensitas perdagangan akan semakin rendah. Variabel jarak menggambarkan biaya transportasi, sehingga ketika jarak meningkat maka biaya transportasi akan meningkat dan selanjutnya meningkatkan harga ekspor dan menurunkan nilai ekspor komoditi ke negara yang bersangkutan.

\section{Real Effective Exchange Rate (REER)}

REER negara tujuan berpengaruh signifikan dan memiliki hubungan negatif terhadap nilai ekspor alas kaki Indonesia. Hasil estimasi menunjukkan bahwa ketika tejadi kenaikan REER negara tujuan terhadap US\$ (depresiasi) sebesar 1 persen maka akan menurunkan nilai ekspor alas kaki Indonesia di enam negara kawasan ASEAN sebesar 2.2146 persen (ceteris paribus). Hal ini sudah sesuai dengan penelitian
(Safitri 2016) bahwa ketika nilai tukar negara tujuan terdepresiasi maka produk dalam negeri akan lebih murah daripada produk luar negeri sehingga masyarakat akan lebih menyukai barang-barang domestik.

\section{Harga Ekspor}

Harga ekspor alas kaki signifikan dan memiliki hubungan negatif terhadap nilai ekspor komoditi alas kaki Indonesia di enam negara kawasan ASEAN. Nilai probabilitas yang didapatkan dari hasil estimasi sebesar 0.000 dan hasil estimasi menunjukkan bahwa ketika terjadi peningkatan harga ekspor alas kaki sebesar 1 persen maka akan terjadi penurunan ekspor komoditi alas kaki Indonesia ke lima negara di kawasan ASEAN sebesar 1.5790 persen (cateris paribus). Harga yang semakin meningkat maka akan menurunkan nilai ekspor alas kaki di pasar internasional. Hasil penelitian ini didukung oleh studi Pradipta dan Firdaus (2014) bahwa ketika harga ekspor komoditas meningkat maka akan mengakibatkan penurunan permintaan komoditas di negara importir dan membuat negara importir akan mencari pengekspor dari negara lain.

\section{Dayasaing Kompetitif Ekspor Alas Kaki Indonesia ke ASEAN Periode 2010-2014}

\section{Kondisi Faktor}

Faktor produksi meliputi semua sumberdaya yang digunakan sebagai input untuk memproduksi suatu produk, misalnya modal, infrasturktur, tenaga kerja, dan teknologi. Peningkatan kualitas input dapat meningkatkan kualitas dan dayasaing produk yang dihasilkan. Kondisi faktor alas kaki berdasarkan studi literatur diantaranya adalah:

1. Sekitar 44 ribu tenaga kerja di sektor alas kaki nasional terkena pemutusan hubungan kerja (PHK) sepanjang tahun 2013. Pengusaha terpaksa mem- PHK pegawai karena biaya produksi melonjak, seiring kenaikan upah minimum provinsi (UMP) dan tarif dasar listrik (TDL) (-) (Sumber: Berita Satu, 2013).

2. Selama periode Januari-September 2015, investasi sebesar Rp 11.55 triliun yang terdiri dari sektor tekstil sebesar Rp 9.8 triliun meningkat 148 persen dari tahun sebelumnya dan sektor alas kaki mencapai Rp 1.6 triliun 
atau turun sebesar 35 persen dari periode sebelumnya (-) (Sumber: Sindo, 2015).

3. Industri alas kaki masih mengalami kekurangan bahan baku. Utilisasi industri penyamakan kulit sapi dalam negeri baru mencapai 48 persen dan kambing/domba hanya 35 persen dari kapasitas produksi. Industri alas kaki masih kekurangan pasokan bahan baku kulit sebesar 64 persen (-) ( Sumber: Jawa Pos, 2015).

4. Program permesinan dengan memberikan bantuan subsidi potongan harga. Bantuan mesin atau alat juga diberikan bagi IKM alas kaki dan produk kulit (+) (Sumber: Kemenperin).

\section{Kondisi Permintaan}

Nilai ekspor alas kaki Indonesia berfluktuatif untuk negara kawasan ASEAN tahun 2010 sampai 2014, namun nilainya cenderung meningkat. Hal ini berarti bahwa alas kaki Indonesia diminati di pasar ASEAN. Gambar 10 menunjukkan perkembangan nilai ekspor alas kaki untuk enam negara kawasan ASEAN tahun 2010-2014. Kondisi permintaan ekspor alas kaki berdasarkan studi literatur diantaranya adalah:

1. Berdasarkan hasil analisis EPD pada penelitian ini terhadap 6 negara kawasan ASEAN menunjukkan bahwa alas kaki Indonesia sebagian besar berada pada posisi falling star (-).

2. Berdasarkan hasil analisis penelitian ini, jarak ekonomi berhubungan negatif dengan nilai ekspor alas kaki Indonesia (-).

3. Pangsa pasar alas kaki Indonesia di pasar dunia mencapai 2,85 persen pada 2014 dan menduduki peringkat 6 di dunia $(+)$ (Sumber: Sindo, 2015).

4. Ekspor industri alas kaki terus mengalami peningkatan, dimana pada tahun 2014 nilai ekspor alas kaki nasional mencapai USD 4,11 miliar atau naik sebesar 6,44 persen dibanding tahun sebelumnya (+) (Sumber: Kemenperin, 2015)

\section{Industri Penunjang}

1. Industri alas kaki dan barang jadi kulit yang didukung oleh industri penyakan kulit sebagai industri hulunya merupakan salah satu sektor industri strategis dan prioritas untuk dikembangkan berdasarkan Rencana Induk Pembangunan Industri Nasional (RIPIN) 2015-2035 (+) (Sumber: Aprisindo, 2016).

1. Industri alas kaki bekerjasama dengan Italia dalam peningkatan teknologi untuk meningkatkan dayasaing alas kaki Indonesia (+) (Sumber: Antara News, 2016).

\section{Strategi, Struktur dan Persaingan Industri}

Kondisi persaingan alas kaki indonesia di kawasan ASEAN cukup ketat. Dengan adanya kerjasama antar negara ASEAN akan menghilangkan hambatan tarif dan memudahkan arus barang untuk masuk dan keluar. Sehingga alas kaki Indonesia harus dapat meningkatkan dayasaing agar dapat bersaing di pasar ASEAN. Kondisi Strategi, Struktur dan persaingan alas kaki diantaranya adalah:

1. Pesaing alas kaki Indonesia di pasar internasional antara lain China, Italia, Vietnam, Jerman, dan Belgia (-) (Sumber: Sindo, 2015).

2. Strategi melalui perbaikan infrastruktur dan perburuhan, Indonesia berpotensi merebut pasar TPT dan alas kaki global yang masing- masing mencapai US\$ 700 miliar dan US\$ 200 miliar per tahun (+) (Sumber: Berita Satu, 2015).

\section{Kebijakan Pemerintah}

Kebijakan pemerintah merupakan peranan penting dalam peningkatan ekspor alas kaki Indonesia. berdasarkan studi literatur maka kebijakan pemerintah dalam ekspor alas kaki diantaranya adalah :

1. Peningkatan kemampuan terutama ergonomical design industri alas kaki yang telah memiliki pangsa pasar tinggi untuk pasar global (Sumber: Berita Satu, 2015).

2. Pengembangan brand alas kaki nasional (+) (Sumber: Kemenperin, 2015).

3. Peremajaan mesin/peralatan industri TPT yang sebagian besar telah berusia di atas 20 tahun. Untuk industri TPT program ini telah dilaksanakan sejak tahun 2007 dan tahun 2009 untuk industri Alas Kaki dan Penyamakan Kulit (+) (Sumber: Berita Satu, 2013). 
4. PP No.78/2015 dalam penetapan upah minimum untuk menjamin kepastian usaha bagi industri alas kaki dan industri padat karya (Sumber: Aprisindo, 2017).

\section{Kesempatan}

1. Industri alas kaki menjadi semakin profesional. Selama ini industri alas kaki berada di belakang diantara industri fashion lainnya $(+)$ (Sumber: Kemendag, 2017).

2. Berdasarkan hasil analasis EPD, sebagian besar negara tujuan berada pada posisi falling star dan rising star, hal ini berarti pangsa pasar di negara tujuan meningkat (+).

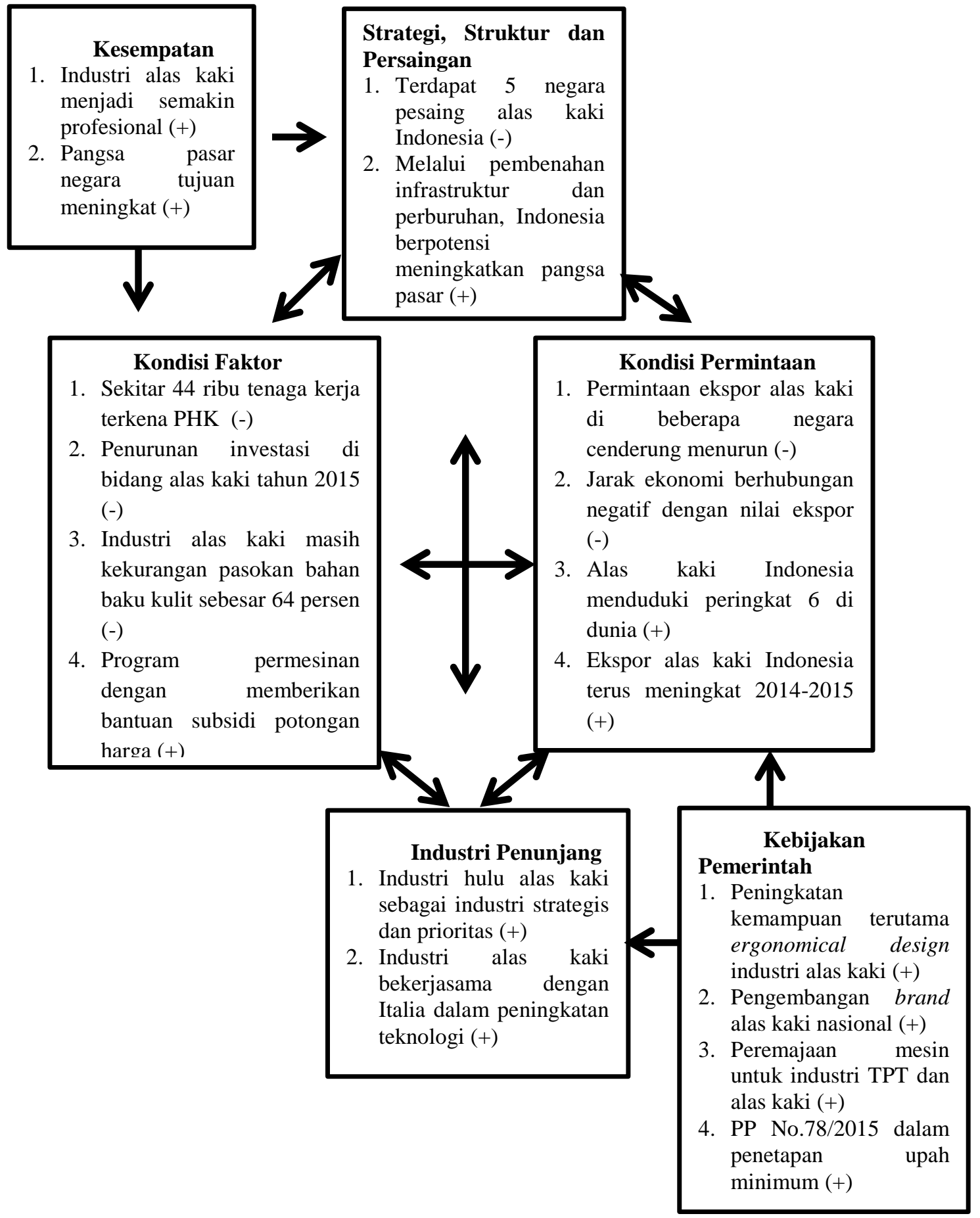

Gambar 10. Porter's diamond model 
Berdasarkan diagram porter's diamond, kelima faktor penting yang dianalisis dalam meningkatkan dayasaing alas kaki sebagian besar menunjukkan hasil positif. Kondisi faktor menunjukkan bahwa terdapat tiga faktor yang menghambat ekspor alas kaki dan hanya satu faktor yang menunjang ekspor alas kaki. Strategi yang dapat dilakukan diantaranya adalah pemerintah harus menegakkan pelaksanaan PP No.78/2015 dalam penetapan upah minimum untuk menjamin kepastian usaha bagi industri alas kaki dan industri padat karya umumnya. Pemerintah harus menjaga upah minimum di sektor industri padat karya agar kompetitif dan bisa bersaing di pasar internasional. Kendala yang menyebabkan investasi menurun pada tahun 2015 adalah proyek perluasan investasi industri seperti pembangunan pabrik sepatu nasional sudah selesai. Untuk dapat meningkatkan investasi di sektor ini, maka industri alas kaki harus dapat terus meningkatkan kualitas dan nilai ekspornya sehingga investor tertarik menanamkan modal pada sektor alas kaki. Selanjutnya, membuat kebijakan tata niaga impor dan peraturan ekspor untuk kulit mentah sebagai bahan baku industri kulit.

Kondisi permintaan alas kaki kawasan ASEAN menunjukkan bahwa dua faktor bernilai positif dan dua faktor bernilai negatif. Strategi yang dapat dilakukan untuk faktor negatif adalah peningkatan kualitas alas kaki sehingga dapat diminati di pasar internasional dan melakukan perjanjian atau kerjasama yang dapat menghilangkan hambatan tarif sehingga menekan biaya produksi. Industri penunjang dan terkait untuk alas kaki adalah industri hulu alas kaki yang sudah dijadikan industri prioritas dan strategis karena nilai ekspor alas kaki sebagai salah satu penyumbang terbesar dalam perekonomian Indonesia.

Struktur, strategi dan persaingan dalam sektor alas kaki memiliki satu faktor positif dan satu faktor negatif. Pembenahan infrastruktur dan mengatasi masalah ketenagakerjaan dapat menekan biaya produksi dan meningkatkan dayasaing alas kaki sehingga berpotensi meningkatkan pangsa pasar alas kaki. Untuk lima negara pesaing alas kaki, agar alas kaki Indonesia tetap diminati di pasar internasional maka sektor alas kaki harus melakukan peningkatan teknologi dana pengembangan brand alas kaki nasional. Selanjutnya, untuk kesempatan sektor alas kaki yaitu industri alas kaki menjadi industri profesional. Hal ini berarti alas kaki sudah menjadi fashion yang diutamakan oleh masyarakat. Kondisi negara yang dianalisis menggunakan EPD sebagian besar berada pada kondisi rising star dan falling star sehingga pangsa pasar meningkat dan Indonesia berpotensi untuk terus memperluas pangsa pasar komoditi unggulannya.

Kebijakan pemerintah yang dapat membantu dalam peningkatan ekspor alas kaki Indonesia diantara nya adalah Peningkatan kemampuan terutama ergonomical design industri alas kaki sehingga produk alas kaki Indonesia mampu bersaing dengan produk pesaing, pengembangan brand alas kaki nasional, Peremajaan mesin/peralatan industri TPT dan alas kaki yang sebagian besar telah berusia di atas 20 tahun dan untuk industri alas kaki sudah dimulai sejak tahun 2009 dan PP No.78/2015 dalam penetapan upah minimum untuk menjamin kepastian usaha bagi industri alas kaki dan industri padat karya diharapkan mampu meningkatkan produksi dan kualitas alas kaki nasional.

\section{SIMPULAN DAN SARAN}

\section{Simpulan}

Analisis keunggunlan komparatif menunjukkan bahwa alas kaki Indonesia yang baik di pasar Singapura, Thailand, Filipina, Brunei dan Vietnam. Hanya negara Malaysia yang tidak memiliki keunggulan komparatif selama periode 2010 sampai 2014. Analisis porter's diamond menunjukkan dayasaing kompetitif yang kuat. Kondisi faktor merupakan satu-satunya kondisi yang menjadi kelemahan dalam ekspor alas kaki Indonesia.

Hasil analisis EPD komoditi alas kaki Indonesia menempati posisi falling star pada negara Malaysia, Singapura dan Vietnam. Kondisi rising star dialami oleh Thailand. Sementara Filipina dan Brunei berada pada kondisi retreat.

Hasil estimasi menggunakan gravity model menunjukkan pertumbuhan GDP perkapita Indonesia, REER, jarak ekonomi dan harga ekspor memiliki hubungan negatif dan signifikan 
terhadap ekspor alas kaki Indonesia. Sementara pertumbuhan GDP perkapita negara tujuan memiliki hubungan positif dan signifikan terhadap nilai ekspor alas kaki Indonesia. Keragaman variabel dependen dapat dijelaskan oleh variabel-variabel independen dalam model sebesar 99.93 persen.

\section{Saran}

Upaya yang harus dilakukan pemerintah melalui Kementrian Perdagangan dan Kementrian Perindustrian harus dapat mendukung dalam menciptakan inovasi di industri alas kaki sehingga meningkatkan dayasaing alas kaki khususnya untuk negara Malaysia.

Pemerintah perlu memberikan perhatian khusus berupa pengembangan kualitas dan brand ke negara yang mengalami penurunan pangsa pasar dan permintaan ekspornya yaitu Filipina dan Brunei.

Pemerintah harus meningkatkan dayasaing di negara Filipina karena memiliki jumlah populasi yang tinggi sehingga pangsa pasar juga tinggi.

\section{DAFTAR PUSTAKA}

Anhar, N. 2016. Analisis kinerja ekspor tesktil dan produk tekstil (TPT) Indonesia ke Amerika Latin periode tahun 2009 sampai 2013 [skripsi]. Bogor (ID): Institut Pertanian Bogor.

[Aprisindo] Aprisindo. [diunduh 2017 Maret]. Tersedia pada: http://www.aprisindo.or.id/

[Antara] Antara News. [diunduh 2017 Maret]. Tersedia pada: http://www.antaranews.com/

[Beritasatu] Berita Satu. [diunduh 2017 Maret]. Tersedia pada: http://www.beritasatu.com/

[Bisnis] Bisnis Indonesia. [diunduh 2017 Maret]. Tersedia pada: http://www.bisnis.com/

[BPS] Badan Pusat Statistik [Internet]. [diunduh pada 2016 Februari]. Tersedia pada: http://bps.go.id.

[CEPII] Centre d'Etudes Prospectives et d'Informations Internationales. Geodesic Distances [Internet]. [diunduh 2016 Februari]. Tersedia pada: http://www.cepii.fr/distance/dist_cepii.z ip

Firdaus M. 2011. Aplikasi Ekonometrika Untuk Data Panel dan Time Series. Bogor (ID): IPB Press.

Gujarati DN, Porter DC. 2009. Basic Econometrics, 5th edition. New York (US): McGraw-Hill.

Hakim L dan Dahalan J. 2009. The global financial crisis and economic integration : evidence on ASEAN-5 countries. Journal of Indonesian Economy and Business 24(3): 291-300.

Hanoum, FN. 2016. Analisis kinerja ekspor elektronika indonesia ke Amerika Latin [skripsi]. Bogor (ID): Institut Pertanian Bogor.

[Jawapos] Jawa Pos. [diunduh 2017 Maret]. Tersedia pada: http://www.jawapos.com/

[Kemendag] Kementrian Perdagangan Republik Indonesia. [diunduh 2017 Februari]. Tersedia pada: http://www.kemendag.go.id/

[Kemenperin] Kementrian Perindustrian Republik Indonesia. [diunduh 2017 Februari]. Tersedia pada: http://www.kemenperin.go.id/.

Kusuma RL, Firdaus M. 2015. Dayasaing dan faktor yang memengaruhi volume ekspor sayuran Indonesia terhadap negara tujuan utama. Jurnal Manajemen dan Agribisnis 12(3): 226236.

Mankiw NG. 2007. Makroekonomi, Edisi 6. Fitria L, Imam N, penerjemah. Jakarta (ID): Erlangga. Terjemahan dari: Macroeconomics 6thEdition.

[Metro] Metro News. [diunduh 2017 Maret]. Tersedia pada: http://www.metrotvnews.com/

Oktaviani R, Novianti T. 2009. Teori Perdagangan dan Aplikasinya di Indonesia. Bogor (ID): Institut Pertanian Bogor.

Pradipta A, Firdaus M. 2014. Posisi dayasaing dan faktor-faktor yang memengaruhi ekspor buah-buahan Indonesia. Jurnal Manajemen dan Agribisnis 11(2): 129143. 
Porter M. 1990. The Competitive Advantage of Nation. New York (USA): Harvard Business Review.

Safitri, A. 2016. Posisi dayasaing dan faktorfaktor yang memengaruhi ekspor otomotif Indonesia ke negara tujuan utama tahun 2009-2014 [skripsi]. Bogor (ID): Institut Pertanian Bogor.

Salvatore D. 1997. Ekonomi Internasional. Haris M, penerjemah. Jakarta (ID): Erlangga. Terjemahan dari: International Economic.

[Sindo] Sindo News. [diunduh 2017 Maret]. Tersedia pada: http://www.sindonews.com/

[UNCOMTRADE] International Trade Statistics Database [diunduh 2017 Februari]. Tersedia pada http://www.uncomtrade.org.

[UNCTADSTAT] United Nations Conference On Trade and Development. [diunduh 2017 Februari]. Tersedia pada: http:// www.uncomtrade.org.
Waristi FV. 2014. Religion and cultural factors in bilateral trade between Indonesia and ASEAN member countries. Jurnal Kajian Ekonomi dan Keuangan 18(2): 85-98.

[WITS] World Integrated Trade Solution. [diunduh Februari 2016]. Tersedia pada: http://wits.worldbank.org.

World Bank. [diunduh 2016 Januari - 2016 Februari]. Tersedia pada: http://www.worldbank.org

Yunia, SN. 2015. Analisis dayasaing dan faktorfaktor yang memengaruhi ekspor alas kaki Indonesia ke Amerika Latin [skripsi]. Bogor (ID): Institut Pertanian Bogor.

Zahro BA. 2013. Analisis dayasaing dan faktorfaktor yang memengaruhi aliran ekspor alas kaki indonesia di kawasan Asean dan China [skripsi]. Bogor (ID): Institut Pertanian Bogor. 